\title{
High fluvial export of dissolved organic nitrogen from a peatland catchment with elevated inorganic nitrogen deposition
}

\author{
D.A. Edokpa ${ }^{*}$, M.G. Evans and J.J. Rothwell \\ Upland Environments Research Unit, School of Environment, Education and Development, \\ The University of Manchester, Oxford Road, M13 9PL, United Kingdom \\ *donald.edokpa@manchester.ac.uk(Tel: +44 (0) 161275 3624)
}

\section{Abstract}

This study investigates seasonal concentrations and fluxes of nitrogen $(\mathrm{N})$ species under stormflow and baseflow conditions in the peat dominated Kinder River catchment, south Pennines, UK. This upland region has experienced decades of high atmospheric inorganic $\mathrm{N}$ deposition. Water samples were collected fortnightly over one year, in combination with high resolution stormflow sampling and discharge monitoring. The results reveal that dissolved organic nitrogen (DON) constitutes $\sim 54 \%$ of the estimated annual total dissolved nitrogen (TDN) flux (14.3 $\left.\mathrm{kg} \mathrm{N} \mathrm{ha}^{-1} \mathrm{yr}^{-1}\right)$. DON cycling in the catchment is influenced by hydrological and biological controls, with greater concentrations under summer stormflow conditions. Dissolved organic carbon (DOC) and DON are closely coupled, with positive correlations observed during spring, summer and autumn stormflow conditions. A low annual mean DOC:DON ratio $(<25)$ and elevated dissolved inorganic $\mathrm{N}$ concentrations (up to 63 $\mu \mathrm{mol} \mathrm{l}^{-1}$ in summer) suggest that the Kinder catchment is at an advanced stage of $\mathrm{N}$ saturation. This study reveals that DON is a significant component of TDN in peatland fluvial systems that receive high atmospheric inputs of inorganic $\mathrm{N}$.

Keywords: south Pennines, Peat, N saturation, DON, Stormflow, Baseflow

\section{Introduction}

Nitrogen $(\mathrm{N})$ is the limiting nutrient of primary production in most ecosystems (Vitousek and Howarth, 1991; Howarth and Marino, 2006) and rarely exceeds $0.5 \mathrm{mg} \mathrm{N} \mathrm{L}^{-1}$ in undisturbed upland catchments (Reynolds and Edwards, 1995). However, there has been increasing evidence that 
atmospheric deposition of $\mathrm{N}$ alters the balance between the retention capacity of soils, biotic cycling and catchment losses, leading to significant impacts on freshwater ecosystems through eutrophication and/or acidification (Allott et al., 1995; Evans et al., 2000; Curtis et al., 2005; Helliwell, et al., 2007a; Gruber and Galloway, 2008; Dise et al., 2011; Durand et al., 2011). A number of studies have investigated total $\mathrm{N}$ flux in catchments (e.g. Allott et al., 1995; Robson and Neal, 1997; Evans et al., 2000; Curtis et al., 2004, 2005; Helliwell et al., 2007a, 2007b), but many have focused on dissolved inorganic nitrogen $\left(\mathrm{DIN}=\mathrm{NO}_{3}-\mathrm{N}\right.$ plus nitrite $\left(\mathrm{NO}_{2}-\mathrm{N}\right)$ plus ammonium $\left(\mathrm{NH}_{4}-\mathrm{N}\right)$ ), to the near exclusion of dissolved organic nitrogen (DON). Although reactive, and perhaps the most significant with respect to water quality, DIN represents only a portion of the total dissolved nitrogen (TDN) flux. In temperate uplands where peat soils dominate (Adamson et al., 1998; Chapman et al., 2001a), and in streams draining both disturbed and undisturbed watersheds (Campbell et al., 2000; Willett et al., 2004; Brookshire et al., 2005; Martinelli et al., 2010; Vogt et al., 2013), DON can contribute substantially to TDN.

The inadequate characterisation of DON as a component of TDN has led to a limited understanding of its dynamics in upland fluvial systems. This dearth of knowledge is highlighted by the omission of organic $\mathrm{N}$ in major water monitoring programmes of the $\mathrm{UK}$ in particular and Europe in general. However, since the late 1990s, there has been recognition of the potential significance of DON in the TDN flux of upland regions (Adamson et al., 1998; Chapman and Edwards, 2001; Chapman et al., 2001a; Clark et al., 2004; Cundill et al., 2007; Helliwell et al., 2007a, 2007b; Vogt et al., 2013). Most UK studies have focused on the uplands of SW England, Scotland, Wales and the North Pennines. On average, DON accounted for more than $40 \%$ of the TDN flux in these upland regions (Reynolds and Edwards, 1995; Adamson et al., 1998; Chapman et al., 2001a; Chapman and Edwards, 2001). However, knowledge of DON is still limited in systems receiving high levels of inorganic $\mathrm{N}$ deposition.

Several studies have shown that an initial increase in inorganic $\mathrm{N}$ deposition leads to an increase in carbon (C) storage through assimilation by vegetation or storage in soil organic matter (SOM) 
(Holland et al., 1997; Rowe, et al., 2006; Evans et al., 2006a). But, if a sustained increase in inorganic $\mathrm{N}$ deposition is not accompanied by an increase in reactive $\mathrm{C}$, the soil $\mathrm{C} / \mathrm{N}$ ratio will decline, resulting in an increase in $\mathrm{N}$ concentration in soil solution, and subsequent leaching to the aquatic environment, including freshwaters (Holland et al., 1997; Goodale et al., 2000; Rowe et al., 2006). A change in the winter-summer seasonal pattern of DIN concentration is a signal of $\mathrm{N}$ saturation and leaching in upland streams and rivers (Helliwell et al., 2007a). In unperturbed upland environments, DIN concentration will be low in summer when biological uptake exceeds supply of $\mathrm{N}$ from atmospheric deposition, mineralisation and nitrification (Reynolds and Edwards, 1995). Contrastingly, with an increase in atmospheric deposition of $\mathrm{N}$ and a decline in biological uptake in winter, higher DIN concentrations in soil solution and stream water are often observed (Reynolds and Edwards, 1995). This seasonal pattern is climate driven, with temperature and moisture playing crucial roles (Birch, 1960; Reynolds et al., 1992; Monteith, et al., 2000). The winter-summer seasonal patterns of DON tend to exhibit more variability between regions (Chapman et al., 2001a; Clark et al., 2004; Helliwell et al., 2007a). For example, in the Scottish uplands, Chapman et al (2001a) observed higher DON concentration in summer than in winter (with some variations in the ratio of seasonal mean concentration between regions), but Clark et al (2004) found no consistent seasonal DON trend at their sites in Scotland. Similar variability in DON was observed in south Pennines sites (Helliwell et al., 2007a). This variation reflects broad differences in catchment characteristics, including soil type, vegetation coverage and the soil C-N pools (Chapman et al., 2001a; Helliwell et al., 2007a).

Although DIN is expected to constitute a greater proportion of TDN in areas with long-term high atmospheric inorganic $\mathrm{N}$ deposition (Allott et al., 1995), the relative importance of organic $\mathrm{N}$ accumulation in peat-dominated ecosystems may vary along a deposition gradient, depending on direct biomass uptake of atmospheric N, and the rate of litter decomposition (Yesmin et al., 1995). Over a period of time, high atmospheric inorganic $\mathrm{N}$ deposition may alter the soil microbial processing of organic matter $(\mathrm{OM})$ and/or the availability of organic substrates that lead to 
DON/dissolved organic carbon (DOC) formation, resulting in marked losses of DON/DOC to the fluvial environment (Pregitzer et al., 2004), especially under storm conditions (Clark et al., 2007; Inamdar and Mitchell, 2007). Whilst there are indications that concentrations and/or composition of $\mathrm{N}$ species and DOC could vary under different flow conditions and environments (Buffam et al., 2001; Williams et al., 2001; Inamdar and Mitchell, 2006, 2007; Neff et al., 2013), significant gaps in our understanding of the temporal dynamics and transport mechanism of these nutrients, particularly in peatland systems, remain (Clark et al., 2007). The rapid shifts in stream flow during storm events, and the significant heterogeneity in the hydro-chemical characteristics of upland catchments (Shand et al., 2005), suggest that routine spot sampling which is widely used for flux calculation in upland systems may not accurately estimate solute or nutrient fluxes, particularly if storms are underrepresented (Clark et al., 2007; Rothwell et al., 2007). This study was undertaken to provide a better understanding of the dynamics of dissolved $\mathrm{N}$ species and $\mathrm{C}$ in peatland systems with a history of high atmospheric $\mathrm{N}$ deposition. We conducted an intensive hydro-chemical monitoring of TDN $[\mathrm{DIN}+\mathrm{DON}]$ and DOC during stormflow and baseflow conditions in an acid-impacted peatdominated catchment of the south Pennines, UK. To our knowledge, this study represents the first investigation into the annual stormflow and baseflow dynamics of TDN [DIN+DON] and DOC in this upland region. We address four key research questions.

1. Do the patterns of DIN and DON differ under baseflow and stormflow conditions? And does temperature, as a proxy for biological activity, influence this pattern?

2. What are the seasonal patterns in $\mathrm{N}$ species and DOC concentration?

3. How significant is DON in the TDN flux?

4. What is the relationship between $\mathrm{N}$ species and DOC?

\section{Study Area}

This study was conducted in the Kinder River catchment covering an area of 394 ha in the Dark Peak area of the south Pennines (Figure 1). The south Pennines has a history of high atmospheric inorganic $\mathrm{N}$ deposition, with current levels at $28 \mathrm{~kg} \mathrm{~N}^{-1} \mathrm{yr}^{-1}$ (Helliwell et al., 2007b). Rainfall for 
the study catchment is $1157 \mathrm{~mm}$, whilst average annual air and water temperature is $8.5^{\circ} \mathrm{C}$ and 7.9 ${ }^{\circ} \mathrm{C}$, respectively (Dec 2012 - Nov 2013). The vegetation of the catchment is dominated by Eriophorum spp (Cotton grass), Vaccinium myrtillus (Bilberry) and Empetrum nigrum (Crowberry). Although low-density sheep grazing occurs within the catchment, land is generally managed to ensure the provision of high water quality. Land management practices typically entails the protection of watercourses, stabilisation of soils, and moorland restoration aimed at reducing organic, particulate and nutrient losses into the fluvial environment (United Utilities, 2011). The soil of the catchment is mainly blanket bog (52\%) and shallow peaty soils (34\%) over grit and coarse sandstone. Approximately $43 \%(1.82 \mathrm{~km})$ of the Kinder River drains Kinder Scout; a grit stone plateau which is overlain by thick deposits (2 to $4 \mathrm{~m}$ depth) of blanket bog incised by erosional gullies. Varying degrees of degradation including vegetation loss, widespread gullying, high sediment and DOC losses, etc. (Evans et al., 2005, 2006; Rothwell et al., 2008a; Allott et al., 2009; Shuttleworth et al., 2014), have been reported in the headwaters of the Kinder plateau. Approximately $22 \%$ of the Kinder plateau (United Utilities, 2011) and 13\% (52 ha) of the Kinder River catchment is bare and eroding peat. The Moors for the Future Partnership is currently undertaking a work to restore the ecological integrity of degraded areas of the Kinder plateau. To this end, 173 ha of the Kinder River catchment headwater have undergone some restoration (between 2010 and 2013), including gully blocking, liming, fertilizer - N (Nitrogen) P(Phosphorus) K (Potassium) application for seeding, and heather brash spreading. In June/July of the hydrological period under investigation (Dec 2012 - Nov 2013), 138 ha of the catchment headwater was limed $\left[\mathrm{CaCO}_{3}(98 \%): \mathrm{MgCO}_{3}(0.5 \%): \mathrm{Si}_{2}(1 \%)\right]$ at an application rate of $1000 \mathrm{~kg} \mathrm{ha}^{-1}$, whilst $28 \%$ (38 ha) of the same area (representing $9.6 \%$ of the entire Kinder catchment area) received maintenance fertilizer [N (40): $\left.\mathrm{P}_{2} \mathrm{O}_{5}(60): \mathrm{K}_{2} \mathrm{O}(60)\right]$ at an application rate of $278 \mathrm{~kg} \mathrm{ha}^{-1}$ (amounting to $\sim 19.5 \mathrm{~kg} \mathrm{~N}$ $\left.\mathrm{ha}^{-1}\right)$.

Figure 1: Study site location 


\section{Methods}

\section{1. $\quad$ Fortnightly water sampling procedure and storage}

Fortnightly grab samples were collected from the outlet of the Kinder River between December 2012 and November 2013. Samples were collected in new 575ml acid-washed Nalgene bottles after pre- rinsing three times in river water. Back at the laboratory, water samples were immediately syringe filtered through a $0.45 \mu \mathrm{m}$ Whatman $\mathrm{G} / \mathrm{F}$ membrane filter into a pre-labelled $20 \mathrm{ml}$ sterile plastic vials and stored at $4{ }^{\circ} \mathrm{C}$ prior to analysis. Samples for $\mathrm{NH}_{4}-\mathrm{N}$ determination were frozen prior to analysis to significantly reduce degradation (Cape et al., 2001).

\section{2. $\quad$ High resolution temporal water sampling}

High resolution storm event sampling was conducted using a Sigma 900 Automatic Water Sampler [AWS]. A total of 96 samples were collected during four storm events (Table 1). The AWS was triggered by a pressure sensor with a rise in stage and was programmed to collect 24 samples of approximately 500ml each, with an inlet rinse between samples. To capture concentration at the rising and falling limb of the hydrograph, a 20 minute sampling interval was set for the first 12 samples, 30 minute for the next 6 samples and $1 \mathrm{hr}$ for the remaining 6 samples. The AWS samples were processed following the methods outlined in the previous section, within $48 \mathrm{hrs}$ of sampling.

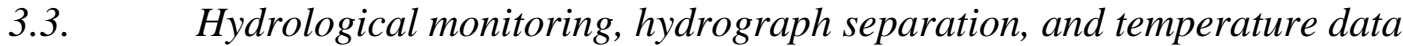

A stage vs discharge $(\mathrm{Q})$ relationship for the monitoring site was established from a series of 9 flow measurements using an electromagnetic flow meter (SENSA RC2) under a range of flow conditions. Stage was continuously recorded every $15 \mathrm{~min}$ on the rated river section using a TruTrack WT-HR 64K capacitance probe with internal data logger, and embedded in hard plastic PVC tube attached to the river bank. A calibrated measuring board was attached to the PVC tube and manually read off at the time of sampling. This provided a check on the performance of the loggers and was used to correct for drift in logger readings. Simple hydrograph separation (Pettyjohn and Henning, 1979; c.f. Rothwell et al., 2008a) was used to split the Q record into baseflow and 
stormflow, across seasons (Table 1). Baseflow was fixed at $\leq 0.15 \mathrm{~m}^{3} \mathrm{~s}^{-1}, \leq 0.10 \mathrm{~m}^{3} \mathrm{~s}^{-1}, \leq 0.09 \mathrm{~m}^{3} \mathrm{~s}^{-1}$ and $\leq 0.12 \mathrm{~m}^{3} \mathrm{~s}^{-1}$ for winter, spring, summer and autumn hydrographs, respectively.

Table 1: Details of water sample collection

In addition to stage, air and water temperature were also recorded for every $15 \mathrm{~min}$ using the TruTrack WT-HR 64K capacitance probe. Temperature has previously been identified as a key environmental control on microbial activity (Zogg et al., 1997), OM decomposition, nutrient release (Agehara and Warncke, 2005; Fenner et al., 2005), mineralization (Zak et al., 1999), and the export of DOC from peatlands (Freeman et al., 2001). Understanding the relationship between temperature, and species of $\mathrm{N}$, as well as DOC will provide useful information about the possible processes driving nutrient patterns in the Kinder River catchment.

\section{4. $\quad$ Water chemistry}

Water samples were analysed for DOC and TDN using a Shimadzu TOC-V CPN ASI-V analyzer with a TNM-1 unit equipped with an autosampler. DIN species were analysed using a Metrohm 882 COMPACT IC PLUS ion chromatograph with inline ultrafiltration system. The detection limit was $0.1 \mathrm{ppm}$ for $\mathrm{NH}_{4}$, and $1 \mathrm{ppm}$ for $\mathrm{NO}_{3}, \mathrm{NO}_{2}$, TDN and DOC. DON was determined by subtracting DIN from TDN. Blank samples (deionized water passed through a $0.45 \mu \mathrm{m}$ Whatman G/F membrane filter) were analysed with each batch of water samples. For all analytical runs, baseline and sensitivity drift checks were repeated after every 10 samples.

\subsection{Flux calculation}

Annual and seasonal fluxes were determined for TDN, DIN and DON. Preliminary analysis of our data revealed variation in the strength of the relationship between $\mathrm{Q}$ and $\mathrm{N}$ species. Hence, to provide a range of estimates of $\mathrm{N}$ flux to the system, river $\mathrm{N}$ fluxes were derived using the regression/ratingcurve method (Haggard et al., 2003; Quilbe et al., 2006) and the Walling and Webb (1985) 'Method 
5' interpolation approach. All measured concentrations and Qs were log transformed before the derivation of rating curves. Using the relevant rating curves, $\mathrm{N}$ concentrations were estimated for every 15 min interval period coinciding with the Q record. The smearing estimator (Duan, 1983) was used to correct for back transformation error of the concentration estimates. Flux was calculated as the product of the estimated 15 min concentrations and corresponding Q. The resulting flux was then determined as the sum of all 15 min fluxes for the monitoring period. Standard error of the regression line was used to calculate the error of the estimated flux. Only concentration data from the fortnightly sampling were used to estimate $\mathrm{N}$ flux using the Walling and Webb (1985) 'Method 5' approach which takes the form:

Total flux $=\frac{K \sum_{i=1}^{n}\left(C_{i \mathrm{i}} Q_{\mathrm{i}}\right)}{K \sum_{i=1}^{n} Q_{\mathrm{i}}} \bar{Q}_{r}$

Where;

$\mathrm{K}=\mathrm{a}$ conversion factor to take into account the period of monitoring

$\mathrm{C}_{i}=$ the concentration associated with each sample point

$\mathrm{Q}_{i}=$ the discharge at time of sampling

$Q_{r}=$ mean discharge over the monitoring period

$n=$ the number of samples

The Walling and Webb (1985) 'Method 5' is the most commonly used interpolation technique for nutrient flux estimation (e.g. Worrall and Burt, 2005; Pawson et al., 2008) when field measurements of concentrations are much fewer relative to Q record (Littlewood, 1992). The simple hydrograph separation technique (Pettyjohn and Henning, 1979; c.f. Rothwell et al., 2008a) was used to provide an independent check on both methods of nutrient flux estimation. The hydrograph separation technique involve multiplying the baseflow and stormflow contributions in litres by the average measured concentration under the two hydrological conditions, respectively, which were then summed to give total nutrient flux. 
All spatial data for the study was loaded into Terrain Analysis System (TAS GIS) (Lindsay, 2005) and ESRI ArcGIS 10 software packages. Flow direction, accumulation, stream network and catchment area delineation were carried out using TAS GIS. The degree of association between concentration of $\mathrm{N}$ species, DOC, temperature, and between DIN and the DOC:DON ratio were examined using bivariate Pearson correlation. The relationship between Q, and N species and DOC were also examined using scatterplots, linear regression and line graphs. Summary statistics for annual and seasonal $\mathrm{N}$ species and DOC concentrations were presented using tables. Statistical analyses were performed in Microsoft Excel 2013 or IBM SPSS Statistics 20.

\section{Results}

\subsection{Temporal dynamics of $N$ species and DOC}

Table 2 shows the temporal dynamics of dissolved N, DOC, and DOC:DON across a range of Q conditions during the hydrological year (Dec 2012 - Nov 2013). The average concentration of DON, and the percentage DON of TDN, increased with higher Q, until Q was $>0.40 \mathrm{~m}^{3} \mathrm{~s}^{-1}$. Similarly, there was an initial increase in average DOC concentration with Q, until Q was $>0.20 \mathrm{~m}^{3} \mathrm{~s}^{-1}$. Although an initial increase in DIN with Q was observed $\left(35-44 \mu \mathrm{mol}^{-1}\right)$, the percentage change was smaller in comparison with DON and DOC, and remained fairly constant with no clear evidence of soil flushing or a dilution effect with rising $\mathrm{Q}$. The mean DOC:DON range was $25-36$ during the $\mathrm{Q}$ interval $<0.11-0.20 \mathrm{~m}^{3} \mathrm{~s}^{-1}$, whereas the value was $\leq 24$ under higher $\mathrm{Q}$ conditions $\left(0.21->0.40 \mathrm{~m}^{3} \mathrm{~s}\right.$ $\left.{ }^{1}\right)$.

Table 2: Summary statistics of the temporal dynamics of dissolved N, DOC concentrations ( $\mu$ mol l${ }^{1}$ ), and DOC:DON molar ratio during the study period 
The results also reveal a similarity in the temporal dynamics of DON and DOC, particularly during the spring storm event (Figure 2a and c; NB: The rising and falling limb). DON and DOC concentrations increased at a similar rate with $\mathrm{Q}$, and both reached their peaks $1 \mathrm{hr} 15 \mathrm{~min}$ after the Q peak; indicating a coupling during the storm event. Contrastingly, DIN concentrations increased gradually on the rising limb of the storm hydrograph and remained fairly constant after attaining its peak (3 hrs $15 \mathrm{~min}$ ) on the recession limb (Figure 2e). DON and DOC concentrations showed similar lagged responses to Q (Figure $2 \mathrm{~b}$ and $\mathrm{d}$ ) and produced a Type A2 concentration-Q (C-Q) hysteresis (Evans and Davies, 1998), in which the highest contributing component to concentration during the storm event is indicative of soil water $\left(\mathrm{C}_{\mathrm{SO}}\right)$, followed by surface event water $\left(\mathrm{C}_{\mathrm{SE}}\right)$, and then ground water $\left(\mathrm{C}_{\mathrm{G}}\right)$. In contrast, DIN displayed a Type A1 C-Q hysteresis (Figure 2f; Evans and Davies, 1998), in which the component contribution to concentration during the storm event takes the form of $\mathrm{C}_{\mathrm{SO}}>\mathrm{C}_{\mathrm{G}}>\mathrm{C}_{\mathrm{SE}}$.

Figure 2: Concentration-discharge (C-Q) relationships and hysteresis loops for DON (a, b), DOC (c, d) and DIN (e, f) during a spring storm event (12/05/2013).

\section{2. $\quad$ Annual and seasonal patterns of $N$ and DOC concentrations}

Summary statistics of flow-weighted annual and seasonal N, DOC and DOC:DON ratios under different flow conditions are shown in Table 3. Annual average TDN concentration was $83.0 \pm 3 \mu \mathrm{mol}$ $1^{-1}$, but increased to over $100 \mu \mathrm{mol} \mathrm{l}^{-1}$ in spring and summer. Annual average DIN and DON concentrations were $40.5 \pm 1 \mu \mathrm{mol} 1^{-1}$ and $42.4 \pm 2 \mu \mathrm{mol} \mathrm{l}^{-1}$ respectively, with each representing $\sim 50 \%$ of the TDN concentration. DIN accounted for a greater proportion of TDN concentration in winter and spring, whilst DON was the dominant form of TDN in summer and autumn. Under combined (stormflow and baseflow) flow conditions, DON and DOC concentration was low in winter but high in summer. This same pattern was observed in DIN concentration. However, the seasonal patterns of DIN and DON varied under different flow conditions. During baseflow, concentrations of DIN were 
generally higher than those of DON, with clear winter-maxima and low summer concentrations. But the reverse pattern was observed under stormflow. DON concentration was high in winter and considerably lower in summer baseflow, but the pattern was switched under stormflow. DON concentration was generally higher than DIN concentration during stormflow, except in spring when DIN concentration was slightly higher. DOC concentration was low in winter, but high in summer under baseflow and stormflow conditions.

Table 3: Annual and seasonal flow-weighted dissolved N and DOC concentrations ( $\mu$ mol $\left.1^{-1}\right)$, and DOC:DON molar ratio under combined flow, stormflow and baseflow conditions

\subsection{Inter-determinant relationships}

Table 4 shows annual and seasonal inter-determinant relationships during storm and baseflow. The inter-determinant relationships varied in strength and direction. For the annual data, there was a strong positive correlation $(p<0.01)$ between DON and DOC, and between DON and DIN during stormflow. A negative relationship $(p<0.01)$ was observed between DIN and DOC during baseflow. Across seasons, except in autumn, no statistically significant $(p<0.01)$ inter-nutrient relationships were observed during baseflow. The limited number of baseflow samples in the winter, spring and summer seasons (Table 1) may be responsible for this observation. A statistically significant $(p<0.01)$ positive relationship was observed between DON and DOC during stormflow in the spring, summer and autumn seasons, and during baseflow in autumn. There was a statistically significant $(p<0.01)$ negative relationship between DON and DIN, and between DIN and DOC under baseflow condition in autumn. Similarly, statistically significant $(p<0.01)$, but negative relationships were obtained between DIN and DOC during stormflow in autumn.

The relationship between temperature and DOC and N species concentration are shown in Table 5. A statistically significant negative relationship was observed between DON and (air and water) temperature during baseflow, whilst DON was positively correlated with water temperature under 
stormflow. Similarly, DOC was positively correlated with air and water temperature during stormflow, but negatively correlated $(p<0.01)$ with air temperature under baseflow condition. A statistically significant negative $(p<0.01)$ relationship was observed between water temperature and DIN concentration under baseflow.

Table 4: Bivariate Pearson correlations between nutrient concentrations $\left(\mu \mathrm{mol} \mathrm{l}^{-1}\right)$ and ratios. Correlations are shown at $p<0.01$

Table 5: Bivariate Pearson correlations between temperature $\left({ }^{\circ} \mathrm{C}\right)$, and the concentration of $\mathrm{N}$ species and DOC $\left(\mu \mathrm{mol} 1^{-1}\right)$. Correlations are shown at $p<0.01(* *)$ and $p<0.05(*)$

\subsection{DOC:DON ratio}

The DOC:DON ratio under different flow conditions are shown in Table 3. Although considerable variability was observed across seasons, the annual average DOC:DON for combined flow conditions was 23. During baseflow, average DOC:DON ratio was $<10 \pm 3$ in winter and spring, but increased substantially to $61 \pm 13$ in summer and $43 \pm 3$ in autumn. Under stormflow condition, average DOC:DON ratio was $<23 \pm 3$ across all seasons except in autumn. There was a statistically significant $(p<0.01)$, but negative relationship between DIN and DOC:DON during annual stormflow and baseflow conditions, and under stormflow in summer and autumn (Table 4). No relationship $(p<0.01)$ was found between DIN and DOC:DON ratio in winter and spring.

\subsection{Fluvial fluxes of $N$}

The annual and seasonal fluvial fluxes of $\mathrm{N}$ in the Kinder River catchment estimated using the different methods are shown in Table 6. Variations were observed in the overall pattern of $\mathrm{N}$ flux depending on the estimation method. Although a poor (almost horizontal) rating relationship was obtained between DIN and $\mathrm{Q}\left(\mathrm{DIN}=0.20(\mathrm{Q})+2.63 ; \mathrm{R}^{2}=0.08\right.$, Adj $\left.\mathrm{R}^{2}=0.07\right)$ (Figure 3a), the effect on the overall DIN flux estimate $\left(6.35 \pm 2.20 \mathrm{~kg} \mathrm{~N} \mathrm{ha}^{-1} \mathrm{yr}^{-1}\right)$ in comparison to the interpolation 
estimate (6.55 $\left.\mathrm{kg} \mathrm{N} \mathrm{ha}^{-1} \mathrm{yr}^{-1}\right)$ was actually minimal. This suggests that interpolation method is well suited for nutrient data not influenced by Q dynamics. On the contrary, the rating curve approach is more appropriate for estimating fluxes of nutrients whose delivery is driven by Q. A good rating relationship was observed between $\mathrm{DON}$ and $\mathrm{Q}\left(\mathrm{DON}=0.71(\mathrm{Q})-0.03 ; \mathrm{R}^{2}=0.35, \mathrm{Adj} \mathrm{R}^{2}=0.35\right)$ (Figure 3b), and produced an estimated annual DON flux $\left(7.79 \pm 3.54 \mathrm{~kg} \mathrm{~N} \mathrm{ha}^{-1} \mathrm{yr}^{-1}\right.$ ), double that of the estimate from the interpolation method $\left(2.60 \mathrm{~kg} \mathrm{~N} \mathrm{ha}^{-1} \mathrm{yr}^{-1}\right)$.

Figure 3: Linear regression relationship between Q and DIN (a) and DON (b) for Kinder River water samples.

About $80 \%$ of annual TDN flux occurred during stormflow. Based on the above analysis, the interpolation approach and rating curve technique is adopted as the best method for estimating fluxes of DIN and DON, respectively, in this study. TDN is then determined as the sum of DIN and DON estimated separately using the relevant estimation method (Table 7). Annual fluvial output of TDN was $\sim 14 \mathrm{~kg} \mathrm{~N} \mathrm{ha}^{-1} \mathrm{yr}^{-1}$, with DON constituting $\sim 54 \%$ of load (Table 7). Similar to DIN, DON flux

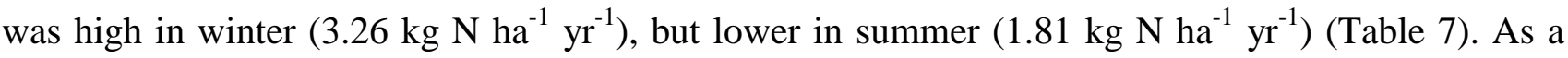
proportion of TDN flux, DON constituted a greater proportion in all but the spring season (Table 7). DIN flux was proportionally higher than DON flux during baseflow (Table 6). In contrast, fluxes of DON were higher than those of DIN during stormflow except in the spring season when DIN made up $\sim 56 \%\left(0.20 \pm 0.07 \mathrm{~kg} \mathrm{~N} \mathrm{ha}^{-1} \mathrm{yr}^{-1}\right)$ of the TDN flux (Table 6).

Table 6: Annual and seasonal $\mathrm{N}$ fluxes shown in $\mathrm{kg} \mathrm{N} \mathrm{ha}^{-1} \mathrm{yr}^{-1}$ using the rating curve technique including error of the estimate; Walling and Webb (1985) 'method 5' shown in parentheses and simple hydrograph separation technique shown in square brackets

Table 7: Best estimate of annual and seasonal $\mathrm{N}$ fluxes $\left(\mathrm{kg} \mathrm{N} \mathrm{ha}^{-1} \mathrm{yr}^{-1}\right)$ for the Kinder River 


\section{Discussion}

\section{1. $\quad N$ and $C$ dynamics}

Understanding the effect of $\mathrm{N}$ loadings on the functioning of ecosystems requires adequate knowledge of its chemical forms and how changes in the hydrologic or biogeochemical conditions affect their speciation and support for ecosystem processes. The results of this study highlight the dynamics of $\mathrm{N}$ under different flow conditions of a peat dominated catchment in the south Pennines, UK. Despite a history of high atmospheric inorganic N deposition, DON constitutes a slightly higher proportion of TDN in the Kinder River catchment. This is consistent with findings in a south Pennine regional-scale study (Helliwell et al., 2007b). The current study reveals marked seasonal variations in the fluvial concentration of N (Table 3). Similar to other studies (e.g. Chapman et al., 2001a; Helliwell et al., 2007a), DON concentrations were higher in summer when biological production is at its peak. Although biological activity in the river and adjacent soil was not directly measured, water and air temperature, respectively, were used as surrogates. A slight $\left(0.8{ }^{\circ} \mathrm{C}\right)$ variation was observed between average air $\left(7.5^{\circ} \mathrm{C}\right)$ and water temperature $\left(6.7^{\circ} \mathrm{C}\right)$ under stormflow conditions, and between average air $\left(9.5^{\circ} \mathrm{C}\right)$ and water $\left(8.7^{\circ} \mathrm{C}\right)$ temperature during baseflow. The observed negative relationship between water temperature and DIN during baseflow (Table 5) suggests the influence of in-stream microbial activities on DIN cycling. Studies have shown that temperature is positively correlated with microbial activity (Zogg et al., 1997; Zak et al., 1999), and is therefore expected to be negatively correlated with DIN (which is utilised by the microbial community), and positively correlated with DON/DOC (which are released during the decomposition of OM) (Hafner et al., 2005). The negative correlation between temperature, and DOC and DON during baseflow (Table 5) suggests that the main driver of these nutrients under baseflow condition may not be internal biological production, but a combination of other spatially distinct factors, including allochthonous inputs and transfer from upstream. Chapman et al (2001b) observed that although temperature influenced microbial activity in a spodosol, it did not affect concentrations of DOC and DON. 
Water table depth modulated by temperature, rainfall distribution (Evans et al., 2002; Worrall et al., 2003) and Q (Tranvik and Jansson, 2002; Pastor et al., 2003) is perhaps the single most important hydrological factor governing OM decomposition and production (Fenner et al., 2009). Gully erosion has caused local water table drawdown immediately adjacent to erosion gullies, and a general lowering of the water table at eroded headwater sites across the Kinder Scout plateau (Allot et al., 2009). In addition, warming from temperature increases evapotranspiration (Worrall et al., 2004), lowers water table (Daniels et al., 2012) and accelerates biological decomposition of the peat matrix (Fenner et al., 2005; 2009). The resultant DOC and DON is then flushed into the fluvial system during storms or rising water tables. The observed positive correlation between temperature, and DOC and DON during stormflow (Table 5) at our site may be due to the flushing of accumulated stores of DOC/DON by warm storms which have been preceded by dry antecedent conditions and associated lower water table. This storm flushing of soils may also transfer substrates to the river and stimulate a rapid short-term increase in heterotrophic activities (Hubbard and Chrzanowski, 1986; Adams et al., 2015), and microbial enzymatic processing of OM (Ritzrau and Graf 1992; Chrost and Riemann, 1994). Billet et al (2006) suggests that temperature-related DOC production in near-surface histosols is likely responsible for the observed linkage between stream DOC concentration and the soil $\mathrm{C}$ pool in the upper $1.5 \mathrm{~km}$ of their study stream.

Our findings (Table 3, Figure $2 \mathrm{a}, \mathrm{b}, \mathrm{c}$ and d) reveal that high levels of DON and DOC concentrations are driven by stormflow, and reflect the influence of hydrological flushing of SOM from near surface peat pore water during storms in the Kinder River catchment. This is consistent with findings from other studies in which DON and DOC concentrations (Buffam et al., 2001) and fluxes increased with Q (Lewis and Grant, 1979), in which the latter is generally related to the \%C and $\% \mathrm{~N}$ content of soils (Neff et al., 2000). The coupling of DOC and DON cycling during stormflow (Table 4), and the type of C-Q hysteresis loop they produce (Figure $2 \mathrm{~b}$ and $\mathrm{d}$ ), is an indication of the similarity of source material (peat soil). Chapman et al (2001a) observed positive correlations between DOC and DON in upland streams of Scotland, but suggest that this relationship 
may not be due to similarity of peat source material, as DON (unlike DOC) displayed a wide scatter relationship with \%peat cover of the catchment. However, the observed relationship between DON and \%peat cover (Chapman et al., 2001a) may reflect a limitation of combining samples collected under different flow conditions (i.e. high or low flow) for the analysis, particularly in catchments with active sites of groundwater seepage. In the current study, whilst no relationship was observed between annual DON and DOC concentration under baseflow $(n=33)$, significant $(p<0.01)$ positive correlation was obtained between these nutrients under stormflow ( $\mathrm{n}=88$; Table 4). DIN concentrations exhibited an anticlockwise C-Q hysteresis (Figure 2f) similar to DON and DOC, but had a 3 hrs 15 min lag between peak Q and peak DIN concentration (Figure 2e). This is similar to findings in an Appalachian stream during a summer storm event, in which the $\mathrm{NO}_{3}$ produced an anticlockwise C-Q hysteresis loop, with a 4-24 hrs lag between peak Q and peak $\mathrm{NO}_{3}$ (Buffam et al., 2001). The poor linear relationship between DIN and Q in the Kinder River (Figure 3a) suggests that DIN delivery is simply not driven by Q, but may be influenced by atmospheric deposition or input from shallow groundwater sources. This is consistent with findings in a similar study (Inamdar and Mitchell, 2007), and may help explain high DIN concentration during baseflow, relative to stormflow in winter (Table 3), and why little variation is observed in DIN concentration with increasing Q (Table 2).

Our study clearly shows that despite decades of high atmospheric inorganic $\mathrm{N}$ deposition $(>25 \mathrm{~kg}$ $\mathrm{N} \mathrm{ha}^{-1} \mathrm{yr}^{-1}$ ), DON concentration and flux represents a significant proportion of TDN in the catchment (Table 3 and 7). This is similar to findings in other studies (Yesmin et al., 1995; Pregitzer et al., 2004; Helliwell et al., 2007a). Pregitzer et al (2004) observed a dramatic increase in solution DON/DOC and $\mathrm{NO}_{3}-\mathrm{N}$ from hardwood forests plots with chronic $\mathrm{NO}_{3}-\mathrm{N}$ addition. This is likely related to substrate availability and alteration in the microbial processing of OM (Yesmin et al., 1995; Pregitzer et al., 2004). Although experimental evidence has shown a strong relationship between DOC, DON and DIN dynamics in which the demand for C is controlled by DIN availability, and DON uptake is mediated by microbial demand for DOC (Bernhardt and Liken, 2002; Brookshire 
et al., 2005), no significant relationship was observed between inputs of $\mathrm{N}$ and DOC outputs in an upland peat bog (Worrall et al., 2006). This suggests that the response of DOC/DON to $\mathrm{N}$ deposition in field observations and experimental studies is not consistent, as the response is linked to the form of inorganic $\mathrm{N}$ deposited and adjustment to soil acidity (Evans et al., 2008). Thus, catchment-specific characteristics may determine the response of DON and DOC to inorganic N inputs (Helliwell et al., 2007b).

Peat decomposition may increase the supply of reactive $\mathrm{C}$ in a catchment (Fenner et al., 2009) and help mediate DIN and DON cycling (Evans et al., 2006a; Buckeridge and Jefferies, 2007) through vegetation uptake (Curtis et al., 2004; Rowe et al., 2006). However, a significant proportion of the Kinder River drains areas with sparse vegetation $(\sim 43 \%)$ or bare and eroding peat $(\sim 13 \%)$. This potentially limits vegetation mediated inorganic $\mathrm{N}$ cycling in the catchment. Under this condition, atmospheric deposition of $\mathrm{N}$ and in-channel rate of nitrification (Daniels et al., 2012), may influence the relationship between N species and DOC. Chapman et al (2001b) observed that soil cores without vegetation leached more inorganic $\mathrm{N}$ in comparison to cores with vegetation; with temperature influencing the rate of net mineralisation and leaching. High DIN concentration during baseflow conditions in the current study (Table 3) may therefore be reflective of the catchment response to direct atmospheric deposition of $\mathrm{N}$ and internal cycling, similar to the second stage of catchment $\mathrm{N}$ saturation that is characterised by severely reduced biological demand and accelerated nitrification (Stoddard, 1994). The annual fluvial flux of N (DIN+DON) in the Kinder River is $\sim 51 \%$ of total atmospheric inorganic $\mathrm{N}$ deposition in the south Pennines. This suggests that although the catchment is at an advanced stage of $\mathrm{N}$ saturation, it still retains some mechanism (though reduced) for $\mathrm{N}$ removal, and is not yet a net source of $\mathrm{N}$ to the river (Stoddard, 1994; Aber et al., 1989, 1995).

\subsection{DOC:DON ratio}

The $\mathrm{C} / \mathrm{N}$ ratio has been widely used as a surrogate of $\mathrm{N}$ leaching particularly in forested ecosystems (Dise et al., 1998; Gundersen et al., 1998; Campbell et al., 2000; Rothwell et al., 2008b; Dise et al., 2009). The suggestion is that as the soil $\mathrm{C} / \mathrm{N}$ ratio decreases there will be an increase in 
inorganic $\mathrm{N}$ leaching (mainly as $\mathrm{NO}_{3}$ ) to adjoining water bodies. Sites with $\mathrm{C} / \mathrm{N}$ ratio of $<25$ are considered to be leaching $\mathrm{N}$ or at a high risk of $\mathrm{N}$ leaching, and $\mathrm{C} / \mathrm{N}$ ratios of between 25 and 30 indicates a moderate risk of $\mathrm{N}$ leaching (Gundersen et al., 1998). Soluble C (DOC) and N (DON) have similarly been used to represent the same relationship in aquatic ecosystems (Harriman et al., 1998; Campbell et al., 2000; Chapman et al., 2001a; Bernal et al., 2005). Similar to conclusions in the heavily acidified River Etherow catchment in the south Pennines (Curtis et al., 2004), reduced uptake of atmospheric $\mathrm{N}$ may encourage the direct leaching of atmospheric $\mathrm{N}$ input to the Kinder River. Although inorganic $\mathrm{N}$ is expected to be utilised for biological production during the summer months (Kaushal and Lewis, 2003; Sjoeng et al., 2007), seasonal biological control did not significantly influence DIN concentrations, which varied little across seasons in the Kinder River (Table 3). The overall $\mathrm{N}$ status and reactivity of the $\mathrm{C}$ pool in the catchment may influence its capacity to immobilise inorganic $\mathrm{N}$, with leaching likely to begin at higher $\mathrm{C} / \mathrm{N}$ ratio in soils with substantial proportion of recalcitrant $\mathrm{C}$ than in soils with more labile $\mathrm{C}$ pool (Evans et al., 2006a, 2006b; Rowe et al., 2006). Flow pathways through the soil horizons, coupled with antecedent conditions, may influence the supply of reactive or recalcitrant C (Buffam et al., 2001; Stutter et al., 2012) in the Kinder River catchment; consistent with the marked temporal (Table 2) and seasonal variability (Table 3) in observed DOC:DON. During an August (summer) storm following a dry antecedent condition in a UK podzolic moorland catchment, Stutter et al (2012) observed low DOC:DON ratios (16-28) attributed to flushing of aromatic compounds mainly (53\%) from the B horizon. But during a November (Autumn) storm with antecedent wet conditions DOC:DON ratio was higher (between 35-43), with flow occurring mainly through the O horizon (Stutter et al., 2012). The consistently high DIN concentration and the observed annual and seasonal DOC:DON (Table 3) in addition to the negative relationship observed between DIN and DOC:DON (Table 4), suggest that the Kinder River catchment is in a state of $\mathrm{N}$ saturation and leaching $\mathrm{N}$. 
The input-output budget for the Kinder River catchment reveals that the catchment is still a sink for $\mathrm{N}$ (Table 8). In addition to atmospheric inorganic $\mathrm{N}$ deposition of $\sim 28.0 \mathrm{~kg} \mathrm{~N} \mathrm{ha}{ }^{-1} \mathrm{yr}^{-1}, 9.6 \%$ (38ha) of the Kinder River catchment received $\sim 19.5 \mathrm{~kg} \mathrm{~N} \mathrm{ha}^{-1} \mathrm{yr}^{-1}$ via fertilizer applied to seeded headwater restoration sites during the monitoring period. However, headwater nutrient mass balance (unpublished data) suggests a rapid flushing or utilization (within two weeks) of this applied $\mathrm{N}$ for grass growth. Thus, no major spike in DIN concentration was identified in our fortnightly data. Peterson et al (2001) have previously shown that inorganic $\mathrm{N}$ input to headwater streams is removed within a few tens to hundreds of meters. Our sampling site was $\sim 2.4 \mathrm{~km}$ downstream of the treatment area. Approximately $86 \%\left(41.0 \mathrm{~kg} \mathrm{~N} \mathrm{ha}^{-1} \mathrm{yr}^{-1}\right)$ of the total inorganic $\mathrm{N}$ input to the Kinder River catchment during the study period was retained. Overall, there is a 70\% net retention of TDN (Table 8). In a forested ecosystem in New England, the net retention of TDN ranged from 62 to $89 \%$ (4.7 to $10 \mathrm{~kg} \mathrm{~N} \mathrm{ha}^{-1} \mathrm{yr}^{-1}$ ), with DON constituting 59\% of TDN output (Campbell et al., 2000). In our study catchment, DON accounts for $\sim 54 \%\left(7.79 \pm 3.54 \mathrm{~kg} \mathrm{~N} \mathrm{ha}^{-1} \mathrm{yr}^{-1}\right)$ of the annual TDN flux. This is significant considering that the region has been exposed to decades of high atmospheric inorganic $\mathrm{N}$ deposition (Evans et al., 2000; Helliwell et al., 2007a). Fluxes of DON as proportions of TDN were generally higher $(>54 \%)$ than those of DIN in all but the spring season (Table 7). However, both DON and DIN flux are generally higher in winter and lower in summer; following the rainfall/Q trend. Rainfall/Q will ultimately control solute fluxes so long as the magnitude of change in $\mathrm{Q}$ is greater than the magnitude of decline in concentrations (Clark et al., 2007). Although the Kinder River catchment was under stormflow for only 29\% (107 days in total) of the monitoring period, stormflow accounted for $\sim 81 \%$ of annual DON flux and $\sim 65 \%$ of annual DIN flux (Table 6 ), indicating that hydrology is a significant control on $\mathrm{N}$ delivery, particularly DON, to the Kinder River. 
Table 8: N input-output budget for the Kinder River catchment (Dec 2012-Nov 2013). NB: Atmospheric inorganic $\mathrm{N}$ input for the catchment is represented by the average inorganic $\mathrm{N}$ deposition value for the south Pennines (Helliwell et al., 2007b)

It was not possible to determine the specific input-output budget of DON for the Kinder River catchment, as DON input data was not available. However, Campbell et al (2000) found that DON inputs in precipitation were approximately equal to output in an upland forested ecosystem. Vogt et al (2013) recorded small losses of $\mathrm{N}\left(-1.6 \pm 3.8 \mathrm{~kg} \mathrm{~N} \mathrm{ha}^{-1} \mathrm{yr}^{-1}\right)$ in a moorland peat-dominated catchment covering 621 ha in southern Scotland, with DON accounting for $81 \%$ of TDN export. Similarly, a small net export of DON was recorded in $1997\left(-1.3 \mathrm{~kg} \mathrm{~N} \mathrm{ha}^{-1} \mathrm{yr}^{-1}\right)$ and $1998(-0.03 \mathrm{~kg}$ $\left.\mathrm{N} \mathrm{ha}^{-1} \mathrm{yr}^{-1}\right)$ albeit a net retention $\left(0.18 \mathrm{~kg} \mathrm{~N} \mathrm{ha}^{-1} \mathrm{yr}^{-1}\right)$ in 1996 at a high-elevation catchment in the Colorado Front Range (Williams et al., 2001). Our work confirms the findings in these studies, that DON is a key component in the $\mathrm{N}$ budget of catchments. Current $\mathrm{N}$ deposition models are based on reduced and reactive $\mathrm{N}$, excluding organic $\mathrm{N}$. This could be an oversight given the magnitude of available DON in this acidified upland region. The potential bioavailability of DON (Seitzinger et al., 2002; Kaushal and Lewis, 2003) would also suggest that current models of N deposition may be underestimating bioavailable $\mathrm{N}$. The impact of such underestimation could potentially be the eutrophication/acidification of lakes and upland freshwaters previously classified as not at risk of $\mathrm{N}$ enrichment.

\section{Conclusion}

The south Pennine region with its extensively degraded organic rich soils has been exposed to decades of high atmospheric inorganic $\mathrm{N}$ deposition $\left(>25 \mathrm{~kg} \mathrm{~N} \mathrm{ha}^{-1} \mathrm{yr}^{-1}\right)$. Our study suggests a catchment scale hydro-biogeochemical control on $\mathrm{N}$ cycling that is related to high atmospheric $\mathrm{N}$ loading, and biological processing influenced by temperature. DON is observed to constitute $\sim 54 \%$ of fluvial TDN in the Kinder River catchment. More than $60 \%$ of DON and DIN flux is delivered during stormflow conditions, indicating that catchment hydrology is an important factor in $\mathrm{N}$ 
delivery to the Kinder River. Unlike DON, seasonal variation in DIN concentration was least marked between the vegetative and dormant seasons, with no clear evidence of a strong biological control. This suggests that the catchment is at an advanced stage of $\mathrm{N}$ saturation. Similarly, the annual DOC:DON ratio of $<25$ and the statistically significant $(p<0.01)$, but negative relationships between DIN and DOC:DON further suggests that the catchment is $\mathrm{N}$ saturated and leaching $\mathrm{N}$. The tight coupling of DOC and DON observed during stormflow suggests that both nutrients are flushed from the peat matrix of the catchment. Temperature is positively correlated $(p<0.01)$ with DOC and DON under stormflow, but negatively correlated during baseflow. Reported increases in DOC concentrations in European and North American upland fluvial systems over recent decades (e.g. Worrall et al., 2003; Skjelkvale et al., 2005; Evans et al., 2006c; Monteith et al., 2007) could similarly imply increased DON concentration, even in areas of high inorganic $\mathrm{N}$ deposition. However, high inorganic $\mathrm{N}$ deposition may prevent the recovery of soil $\mathrm{pH}$, such that $\mathrm{DOC}$ mobility will be suppressed (Curtis et al., 2005; Evans et al., 2006c 2008), along with DON. Nonetheless, upland waters are usually nutrient poor, and so any evidence of an increase in DON could be very important, particularly if it is bioavailable.

\section{Acknowledgments}

We are grateful to The University of Manchester for providing a Presidents Doctoral Scholarship Award (to D.A. Edokpa). We thank United Utilities for granting access and permission to conduct this study. Thanks to Alan Heath and Andrew Stimson for their help with logistics and fieldwork, and to Jonathan Yarwood and John Moore for their assistance in the laboratory. Finally, we thank three anonymous reviewers for helpful comments which improved the manuscript. 


\section{References}

Aber, J. D., Magill, A., McNulty, S. G., Boone, R. D., Nadelhoffer, K. J., Downs, M. and Hallett, R. (1995) Forest biogeochemistry and primary production altered by nitrogen saturation, Water Air and Soil Pollution, 85, 1665-1670.

Aber, J.D., Nadelhoffer, K.J., Steudler, P. and Melillo, J.M. (1989) Nitrogen saturation in northern forest ecosystems, BioScience, 39(6), 378-386.

Adams, H.E., Crump, B.C. and Kling, G.W. (2015) Isolating the effects of storm events on artic aquatic bacteria: temperature, nutrients, and community composition as controls on bacterial productivity, Frontiers in Microbiology, 6(250), doi: 10.3389/fmicb.2015.00250.

Adamson, J.K., Scott, W.A. and Rowland, A.P. (1998) The dynamics of dissolved nitrogen in a blanket peat dominated catchment, Environmental Pollution, 99, 69-77.

Agehara, S. and Warncke, D.D. (2005) Soil moisture and temperature effects on nitrogen release from organic nitrogen sources, Soil Science Society of America, 69, 1844-1855.

Allott, T. E. H., Curtis, C. J., Hall. J., Harriman, R. and Battarbee, R. W. (1995) The impact of nitrogen deposition on upland surface waters in Great Britain: a regional assessment of nitrate leaching, Water Air and Soil Pollution, 85, 297-302.

Allott, T.E.H., Evans, M.G., Lindsay, J.B., Agnew, C.T., Freer, J.E., Jones, A. and Parnell, M. (2009) Water tables in Peak District blanket peatlands, Moors for the Future, Report No 17.

Bernal, S., Butturini, A. and Sabater, F. (2005) Seasonal variations of dissolved nitrogen and DOC:DON ratios in an intermittent Mediterranean stream, Biogeochemistry, 75, 351-372.

Bernhardt, E.S. and Likens, G.E. (2002) Dissolved organic carbon enrichment alters nitrogen dynamics in a forest stream, Ecology, 83(6), 1689-1700.

Billett, M.F., Deacon, C.M., Palmer, S.M., Dawson, J.J.C. and Hope, D. (2006) Connecting organic carbon in stream water and soils in a peatland catchment, Journal of Geophysical Research, 111, G02010, doi:10.1029/2005JG000065.

Birch, H.E. (1960) Nitrification in soils after different periods of dryness, Plant and Soil, 12, 81-96.

Brookshire, E. N. J., Valett, H. M., Thomas, S.A., and Webster, J.R. (2005) Coupled cycling of dissolved organic nitrogen and carbon in a forest stream, Ecology, 86(9), 2487-2496.

Buckeridge, K.M. and Jefferies, R.L. (2007) Vegetation loss alters soil nitrogen dynamics in an Artic salt marsh, Journal of Ecology, 95, 283-293.

Buffam, I., Galloway, J.N., Blum, L.K. and McGlathery, K.J. (2001) A storm/baseflow comparison of dissolved organic matter concentrations and bioavailability in an Appalachian stream, Biogeochemistry, 53, 269-306 
Campbell, J.L., Hornbeck, J.W., Mcdowell, W.H., Buso, D.C., Shanley, J.B. and Likens, G.E. (2000) Dissolved organic nitrogen budgets for upland, forested ecosystems in New England, Biogeochemistry, 49, 123-142.

Cape, J.N., Kirika, A., Rowland, A.P., Wilson, D.R., Jickells, T.D. and Cornell, S. (2001) Organic nitrogen in precipitation: Real problem or sampling artefact?, TheScientificWorld, 1(S2), 230-237.

Chapman, P.J. and Edwards, A.C. (2001) Inorganic and Organic Losses of Nitrogen from Upland Regions of Britain: Concentrations and Fluxes, TheScientificWorld, 1(S2), 589-596.

Chapman, P.J., Edwards, A.C. and Cresser, M.S. (2001a) The nitrogen composition of streams in upland Scotland: some regional and seasonal differences, Science of the Total Environment, 265, 6583.

Chapman, P.J., Williams, B.L. and Hawkins, A. (2001b) Influence of temperature cover on soluble inorganic and organic nitrogen in a spodosol, Soil, Biology \& Biochemistry, 33(2001), 1113-1121.

Chrost, R.J. and Riemann, B. (1994) Storm-stimulated enzymatic decomposition of organic matter in benthic/pelagic coastal mesocosms, Marine Ecology Progress Series, 108, 185-192.

Clark, M.J., Cresser, M.S., Smart, R., Chapman, P.J. and Edwards, A.C. (2004) The influence of catchment characteristics on the seasonality of carbon and nitrogen species concentrations in upland rivers of Northern Scotland, Biogeochemistry, 68, 1-19.

Clark, J.M., Lane, S.N., Chapman, P.J. and Adamson, J.K. (2007) Export of dissolved organic carbon from an upland peatland during storm events: Implication for flux estimates, Journal of Hydrology, 347, 438-447.

Curtis, C.J., Evans, C.D., Helliwell, R.C. and Monteith, D.T. (2005) Nitrate leaching as a confounding factor in chemical recovery from acidification in UK upland waters, Environmental Pollution, 137(1), 73-82.

Curtis, C.J., Emmett, B.A., Reynolds, B. and Shilland, J. (2004) Nitrate leaching from moorland soils: Can soil C:N ratios indicate N saturation, Water, Air, and Soil Pollution: Focus, 4, 359-369.

Cundill, A.P., Chapman, P.J. and Adamson, J.K. (2007) Spatial variation in concentrations of dissolved nitrogen species in an upland blanket peat catchment, Science of the Total Environment, 373, 166-177.

Daniels, S.M., Evans, M.G., Agnew, C.T. and Allott, T.E.H. (2012) Ammonium release from a blanket peatland into headwater stream systems, Environmental Pollution, 163, 261-272.

Dise, N.B., Ashmore, M., Belyazid, S. et al. (2011) Nitrogen as a threat to European terrestrial biodiversity. In: M. A. Sutton , C. M. Howard , J. W. Erisman et al. (eds.), The European Nitrogen Assessment, Cambridge University Press.

Dise, N.B., Rothwell, J.J., Gauci, V., van der Salm, C. and de Vries, W. (2009) Predicting dissolved inorganic nitrogen leaching in European forests using two independent databases, Science of the 
Dise, N.B., Matzner, E. and Forsius, M. (1998) Evaluation of organic horizon C:N ratio as a $n$ indicator of nitrate leaching in conifer forests across Europe, Environmental Pollution, 102(S1) 453456.

Duan, N. (1983) Smearing estimate - a nonparametric retransformation method, Journal of the American Statistical Association, 78, 605-610.

Durand, P., Breuer, L., Johnes, P.J. et al. (2011) Nitrogen processes in aquatic ecosystems. In: M. A. Sutton , C. M. Howard , J. W. Erisman et al. (eds.), The European Nitrogen Assessment, Cambridge University Press.

Evans, C.D., Caporn, S.J.M., Carroll, J.A., Pilkington, M.G., Wilson, D.B., Ray, N. and Cresswell, N. (2006a) Modelling nitrogen saturation and carbon accumulation in heathland soils under elevated nitrogen deposition, Environmental Pollution, 143, 468-478.

Evans, C.D., Chapman, P.J., Clark, J.M., Monteith, D.T. and Cresser, M.S. (2006c) Alternative explanations for rising dissolved organic carbon export from organic soils, Global Change Biology, 12, 2044-2053.

Evans, C. and Davies, T.D. (1998) Causes of concentration/discharge hysteresis and its potential as a tool for analysis of episode hydrochemistry, Water Resources Research, 34(1), 129-137.

Evans, C.D., Freeman, C., Monteith, D.T., Reynolds, B. and Fenner, N. (2002) Climate changeterrestrial export of organic carbon-Reply, Nature, 415, 862.

Evans, C.D., Goodale, C.L., Caporn, S.J.M., Dise, N.B., Emmett, B.A., Fernandez, I.J., Field, C.D., Findlay, S.E.G., Lovett, G.M., Meesenburg, H., Moldan, F. and Sheppard, L.J. (2008) Does elevated nitrogen deposition or ecosystem recovery from acidification drive increased dissolved organic carbon loss from upland soil? A review of evidence from field nitrogen addition experiments, Biogeochemistry, 91, 13-35.

Evans, C.D., Jenkins, A. and Wright, R.F. (2000) Surface water acidification in the south Pennines I. current status and spatial variability, Environmental Pollution, 109, 11-20.

Evans, C.D., Reynolds,B., Jenkins, A., Helliwell, R.C., Curtis, C.J., Goodale, C.L., Ferrier, R.C., Emmett, B.A., Pilkington, M.G., Caporn, S.J.M., Carroll, J.A., Norris, D., Davies, J. and Coull, M.C. (2006b) Evidence that Soil Carbon Pool Determines Susceptibility of Semi-Natural Ecosystems to Elevated Nitrogen Leaching, Ecosystems, 9, 453-462.

Evans, M., Allott, T., Holden, J., Flitcroft, C. and Bonn, A. (eds.) (2005) Understanding gully blocking in deep peat, Moors for the Future Report No 4.

Evans, M.G., Crowe, S., Evans, V., Liddaman, L.C., Lindsay, J.B. and Rothwell, J.J. (2006) Gully revegetation and carbon sequestration on bleaklow, Moors for the future partnership, Derbyshire. 
Fenner, N., Freeman, C. and Reynolds, B. (2005) Hydrological effects on the biodiversity of phenolic degrading bacteria in a peatland: implications for carbon cycling, Soil Biology and Biochemistry, 37, 1277-1287.

Fenner, N., Freeman, C. and Worrall, F. (2009) Hydrological controls on dissolved organic carbon production and release from UK peatlands. In: Baird, A.J., Belyea, L.R., Comas, X., Reeve, A.S. and Slatter, L.D., editors. Carbon Cycling in Northern Peatlands. Washington, D.C: Geophysical Monograph Series 184; American Geophysical Union. p. 237-249.

Freeman, C., Evans, C.D. and Monteith, D.T. (2001) Export of organic carbon from peat soils, Nature, 412, 785.

Goodale, C.L., Aber, J.D. and McDowell, W.H. (2000) The long-term effects of disturbance on organic and inorganic nitrogen export in the white mountains, New Hampshire, Ecosystems, 3, 433450.

Gruber, N. and Galloway, J. N. (2008) An Earth-system perspective of the global nitrogen cycle, Nature, 451(7176), 293-296.

Gundersen, P., Callesen, I. and de Vries, W. (1998) Nitrate leaching in forest ecosystems is controlled by forest floor C/N ratio, Environmental Pollution, 102 (S1), $403-407$.

Hafner, S.D., Groffman, P.M. and Mitchell, M.J. (2005) Leaching of dissolved organic carbon, dissolved nitrogen, and other solutes from a coarse woody debris and litter in a mixed forest in New York State, Biogeochemistry, 74, 257-282.

Haggard, B.E., Soerens, T.S., Green, W.R. and Richards, R.P. (2003) Using regression methods to estimate stream phosphorus loads at the Illinois river, Arkansas, Applied Engineering in Agriculture, 19(2), 187-194.

Harriman, R., Curtis, C. and Edwards, A. C. (1998) An empirical approach for assessing the relationship between nitrogen deposition and nitrate leaching from upland catchments in the United Kingdom using runoff chemistry, Water, Air and Soil Pollution, 105, 193-203.

Helliwell, R.C., Davies, J.J.L., Evans, C.D., Jenkins, A., Coull, M.C., Reynolds, B., Norris, D. and Ferrier, R.C. (2007a) Spatial and seasonal variation in nitrogen leaching and acidity across four acidimpacted regions of the UK, Water, Air and Soil Pollution, 185, 3-19.

Helliwell, R.C., Coull, M.C., Davies, J.J.L., Evans, C.D., Norris, D., Ferrier, R.C., Jenkins, A. and Reynolds, B. (2007b) The role of catchment characteristics in determining surface water nitrogen in four upland regions in the UK, Hydrology and Earth System Science, 11, 356-371.

Holland, E.A., Braswell, B.H., Lamarque, J-F.,Townsend, A., Sulzman, J., Muller, J-F., Dentener, F., Brasseur, G., Levy II, H., Penner, J.E. and Roelofs, G-J. (1997) Variations in the predicted spatial distribution of atmospheric nitrogen deposition and their impact on carbon uptake by terrestrial ecosystems, Journal of Geophysical Research, 102(D13), 15849-15866.

Howarth, R.W. and Marino, R. (2006) Nitrogen as the limiting nutrient for eutrophication in coastal marine ecosystems: Evolving views over three decades, Limnology and Oceanography, 51(1, part 2), 364-376. 
Hubbard, J.G. and Chrzanowski, T.H. (1986) Impact of storms on heterotrophic activity of epilimnetic bacteria in a southwestern reservoir, Applied and Environmental Microbiology, 51(6), 1259-1263.

Inamdar, S.P. and Mitchell, M.J. (2006) Hydrologic and topographic controls on storm-event exports of dissolved organic carbon (DOC) and nitrate across catchment scales, Water Resources Research, 42, W03421, doi:10.1029/2005WR004212.

Inamdar, S.P. and Mitchell, M.J. (2007) Storm event exports of dissolved organic nitrogen (DON) across multiple catchments in a glaciated forested watershed, Journal of Geophysical Research, 112, G02014, doi:10.1029/2006JG000309.

Kaushal, S. S. and Lewis, W. M., Jr. (2003) Patterns in the chemical fractionation of organic nitrogen in Rocky Mountain streams, Ecosystems, 6, 483-492.

Lewis, W.M. and Grant, M.C. (1979) Relationships between stream discharge and yield of dissolved substances from a Colorado mountain watershed, Soil Science, 128(6), 353-363.

Lindsay, J.B. (2005) The Terrain Analysis System: a tool for hydro-geomorphic applications, Hydrological Processes, 19(5), 1123-30.

Littlewood, I. G. (1992) Estimating constituent loads in rivers: a review, Institute of Hydrology, Wallingford, UK. Report No. 117.

Martinelli, L.A., Coletta, L.D., Ravagnani, E.C., Camargo, P.B., Ometto, J.P.H.B., Filoso, S. and Victoria, R.L. (2010) Dissolve nitrogen in rivers: comparing pristine and impacted regions of Brazil, Brazilian Journal of Biology, 70(3), 709-722.

Monteith, D.T., Evans, C.D. and Reynolds, B. (2000) Are temporal variations in the nitrate content of UK upland freshwaters linked to the North Atlantic Oscillation?, Hydrological Processes, 14, 1745-1749.

Monteith, D.T., Stoddard, J.L., Evans, C.D., de Wit, H.A., Forsius, M., Hogasen, T., Wilander, A., Sjelkvale, B.L., Jeffries, D.S., Vuorenmaa, J., Keller, B., Kopacek, J. and Vesely, J. (2007) Dissolved organic carbon trends resulting from changes in atmospheric deposition chemistry, Nature, 450, 537-541.

Neff, J.C., Hobbie, S.E. and Vitousek, P.M. (2000) Nutrient and mineralogical control on dissolved organic C, N and P fluxes and stoichiometry in Hawaiian soils, Biogeochemistry, 51, 283-302.

Neff, K.J., Schwartz, J.S., Moore, S.E. and Kulp, M.A. (2013) Influence of basin characteristics on baseflow and stormflow chemistry in the Great Smoky Mountains National Park, USA, Hydrological Processes, 27, 2061-2074.

Pastor, J., Solin, J., Bridgham, S.D., Updegraff, K., Harth, C., Weishampel, P. and Dewey, B. (2003) Global warming and the export of dissolved organic carbon from boreal peatlands, Oikos, 100, 380 386. 
Pawson, R.R., Lord, D.R., Evans, M.G. and Allott, T.E.H. (2008) Fluvial organic carbon flux from an eroding peatland catchment, southern Pennines, UK, Hydrology and Earth Systems Sciences, 12, 625-634.

Peterson, B.J., Wollheim, W.M., Mulholland, P.J., Webster, J.R., Meyer, J.L., Tank, J.L., Marti, E., Bowden, W.B., Valett, H.M., Hershey, A.E., McDowell, W.H., Dodds, W.K., Hamilton, S.K., Gregory, S. and Morrall, D.D. (2001) Control of nitrogen export from watersheds by headwater streams, Science, 292, 86-90.

Pettyjohn, W.A. and Henning, R. (1979) Preliminary estimate of ground-water recharge rates, related streamflow and water quality in Ohio. Ohio State University Water Resources Centre Project Completion Report Number 552.

Pregitzer, K.S., Zak, D.R., Burton, A.J., Ashby, J.A. and MacDonald, N.W. (2004) Chronic nitrate additions dramatically increase the export of carbon and nitrogen from northern hardwood ecosystems, Biogeochemistry, 68, 179-197.

Quilbe, R., Rousseau, A.N., Duchemin, M., Poulin, A., Gangbazo, G. and Villeneuve, J. (2006) Selecting a calculation method to estimate sediment and nutrient loads in streams: Application to the Beaurivage River (Quebec, Canada), Journal of Hydrology, 326, 295-310.

Reynolds, B. and Edwards, A.C. (1995) Factors influencing dissolved nitrogen concentrations and loadings in upland streams of the UK, Agricultural Water Management, 27, 181-202.

Reynolds, B., Emmett, B.A. and Woods, C. (1992) Variations in streamwater nitrate concentrations and nitrogen budgets over 10 years in a headwater catchment in mid-Wales, Journal of Hydrology, $136,155-175$.

Ritzrau, W. and Graf, G. (1992) Increase of microbial biomass in the benthic turbidity zone of Kiel Bight after resuspension by a storm event, Limnology and Oceanography, 37(5), 1081-1086.

Robson, A.J. and Neal, C. (1997) A summary of regional water quality for eastern UK rivers, Science of the Total Environment, 194/195, 15-37

Rothwell, J.J., Evans, M.G., Daniels, S.M. and Allott, T.E.H. (2008a) Peat soils as a source of lead contamination to upland fluvial systems, Environmental Pollution, 153, 582-589.

Rothwell, J.J., Futter, M.N. and Dise, N.B. (2008b) A classification and regression tree model of controls on dissolved inorganic nitrogen leaching from European forests, Environmental Pollution, $156,544-552$.

Rothwell, J.J., Evans, M.G., Daniels, S.M. and Allott, T.E.H. (2007) Baseflow and stormflow metal concentrations in streams draining contaminated peat moorlands in the Peak District National Park (UK), Journal of Hydrology, 341, 90-104.

Rowe, E.C., Evans, C.D., Emmett, B.A., Reynolds, B., Helliwell, R.C., Coull, M.C. and Curtis, C.J. (2006) Vegetation type affects the relationship between soil carbon to nitrogen ratio and nitrogen leaching, Water, Air, and Soil Pollution, 177, 335-347. 
Seitzinger, S.P., Sanders, R.W. and Styles, R. (2002) Bioavailability of DON from natural and anthropogenic sources to estuarine plankton, Limnology Oceanography, 47, 353-366.

Shuttleworth, E.L., Evans, M.G., Hutchinson, S.M. and Rothwell, J.J. (2014) Peatland restoration: controls on sediment production and reductions in carbon and pollutant export, Earth Surface Processes and Landforms; DOI: 10.1002/esp.3645.

Shand, P., Haria, A.H., Neal, C., Griffiths, K.J., Gooddy, D.C., Dixon, A.J., Hill, T., Buckley, D.K. and Cunningham, J.E. (2005) Hydrochemical heterogeneity in an upland catchment: further characterisation of the spatial, temporal and depth variations in soils, streams and groundwaters of the Plynlimon forested catchment, Wales, Hydrology and Earth System Sciences, 9 (6), 621-644.

Sjoeng, A.M.S., Kaste, O., Torseth, K. And Mulder, J. (2007) N Leaching from small upland headwater catchments in south western Norway, Water, Air and Soil Pollution, 179, 323-340.

Skjelkvale, B.L., Stoddard, J.L., Jeffries, D.S., Torseth, K., Hogasen, T., Bowman, J., Mannio, J., Monteith, D.T., Mosello, R., Rogora, M., Rzychon, D., Vesely, J., Wieting, J., Wilander, A. and Worsztynowicz, A. (2005) Regional scale evidence for improvements in surface water chemistry 1990-2001, Environmental Pollution, 137, 165-176.

Stoddard, J.L. (1994) Long-term changes in watershed retention of nitrogen: its causes and aquatic consequences. In: Environmental Chemistry of Lakes and Reservoirs, L. Baker (ed.), 223-284, Advances in Chemistry Series, No. 237, American Chemical Society, Washington, DC.

Stutter, M.I., Dunn, S.M. and Lumsdon, D.G. (2012) Dissolved organic carbon dynamics in a UK podzolic moorland catchment: linking storm hydrochemistry, flowpath analysis and sorption experiments, Biogeosciences, 9, 2159-2175.

Tranvik, L.J. and Jansson, M. (2002) Climate change - Terrestrial export of organic carbon, Nature, $415,861-862$.

United Utilities (2011) Report on adaptation under the Climate Change Act 2000. Accessed on $01 / 04 / 2015$ at $16: 57$ from http://corporate.unitedutilities.com/documents/UUW_Climate_change_adaptation_report_FINAL.pd $\underline{\mathrm{f}}$

Vitousek, P. M. and Howarth, R.W. (1991) Nitrogen limitation on land and sea: How can it occur? Biogeochemistry, 13, 87-115.

Vogt, E., Braban, C. F., Dragosits, U., Theobald, M. R., Billett, M. F., Dore, A. J., Tang, Y. S., van Dijk1, N., Rees, R. M., McDonald, C., Murray, S., Skiba1, U. M. and Sutton, M. A. (2013) Estimation of nitrogen budgets for contrasting catchments at the landscape scale, Biogeosciences, 10, 119-133.

Walling, D. E. and Webb, B. W. (1985) Estimating the discharge of contaminants to coastal waters by rivers: Some cautionary comments, Marine Pollution Bulletin, 16(12), 488-492.

Willett, V.B., Reynolds, B., Stevens, P.A., Ormerod, S.J. and Jones, D.L. (2004) Dissolved organic nitrogen regulation in freshwaters, Journal of Environmental Quality, 33, 201-9. 
Williams, M.W., Hood, E. and Caine, N. (2001) Role of organic nitrogen in the nitrogen cycle of a high-elevation catchment, Colorado Front Range, Water Resources Research, 37(10), 2569-2581.

Worrall, F. and Burt, T. (2005) Predicting the future DOC flux from upland peat catchments, Journal of Hydrology, 300, 126-139.

Worrall, F., Burt, T.P. and Adamson, J. (2006) Do nitrogen inputs stimulate dissolved organic carbon production in upland peat bogs?, Global Biogeochemical Cycles, 20, GB3013, doi:10.1029/2005GB002524.

Worrall F., Burt, T.P. and Shedden, R. (2003) Long terms records of riverine carbon flux, Biogeochemistry, 64, 165-178.

Worrall, F., Harriman, R., Evans, C. D., Watts, C., Adamson, J., Neal, C., Tipping, E., Burt, T. P., Grieve, I., Montieth, D., Naden, P. S., Nisbet, T., Reynolds, B. and Stevens, P. (2004) Trends in dissolved organic carbon in UK rivers and lakes, Biogeochemistry, 70(3), 369- 402.

Yesmin, L., Gammack, S.M., Sanger, L.J. and Cresser, M.S. (1995) Impact of atmospheric N deposition on inorganic and organic N outputs in water draining from peat, Science of the Total Environment, 166, 201-209.

Zak, D.R., Holmes, W.E., MacDonald, N.W. and Pregitzer, K.S. (1999) Soil temperature, matric potential and the kinetics of microbial respiration and nitrogen mineralisation, Soil Science Society of America, 63, 575-584.

Zogg, G.P., Zak, D.R., Ringelberg, D.B., MacDonald, N.W., Pregitzer, K.S. and White, D.C. (1997) Compositional and functional shifts in microbial communities due to soil warming, Soil Science Society of America, 61, 475-481. 
Table 1: Details of water sample collection

\begin{tabular}{|c|c|c|c|c|c|c|}
\hline \multirow[b]{2}{*}{ Season } & \multirow[b]{2}{*}{ Month } & \multicolumn{2}{|c|}{ Storm event sampling with AWS } & \multirow{2}{*}{$\begin{array}{l}\text { Fortnightly } \\
\text { sampling }\end{array}$} & \multicolumn{2}{|c|}{$\begin{array}{l}\text { After hydrograph } \\
\text { separation }\end{array}$} \\
\hline & & Details & Date & & Baseflow & Stormflow \\
\hline Winter & Dec 2012 - Feb 2013 & 1 event ( 24 samples) & $14 / 02 / 13$ & 7 & 3 & 28 \\
\hline Spring & Mar 2013 - May 2013 & 1 event (24 samples) & $12 / 05 / 13$ & 6 & 6 & 24 \\
\hline Summer & June 2013 - Aug 2013 & 1 event (24 samples) & $23 / 06 / 13$ & 6 & 5 & 25 \\
\hline Autumn & Sept 2013 - Nov 2013 & 1 event (24 samples) & $09 / 09 / 13$ & 6 & 19 & 11 \\
\hline Total samples & & 4 events (96 samples) & & 25 & 33 & 88 \\
\hline
\end{tabular}


Table 2: Summary statistics of the temporal dynamics of dissolved $\mathrm{N}$ and DOC concentrations $\left(\mu \mathrm{mol} \mathrm{l}^{-1}\right.$ ), and DOC:DON molar ratio during the study period

\begin{tabular}{clccccc}
\hline $\mathrm{Q}\left(\mathrm{m}^{3} \mathrm{~s}^{-1}\right)$ & Stat parameter & TDN & DIN & DON & DOC & DOC:DON \\
\hline$<0.11$ & Mean & 58 & 35 & 23 & 691 & 36 \\
& Minimum & 29 & 7 & 3 & 132 & 3 \\
& Maximum & 117 & 71 & 58 & 1556 & 99 \\
& \% TDN & & 60 & 40 & & \\
& No. of samples & 30 & 30 & 30 & 30 & 30 \\
\hline $0.11-0.20$ & Mean & 84 & 44 & 40 & 876 & 25 \\
& Minimum & 43 & 13 & 3 & 168 & 5 \\
& Maximum & 135 & 73 & 82 & 1395 & 77 \\
& \% TDN & & 52 & 48 & & \\
& No. of samples & 27 & 27 & 27 & 27 & 27 \\
\hline $0.21-0.30$ & Mean & 97 & 41 & 56 & 812 & 16 \\
& Minimum & 36 & 14 & 12 & 337 & 7 \\
& Maximum & 163 & 63 & 102 & 1497 & 41 \\
& \% TDN & & 42 & 58 & & \\
& No. of samples & 29 & 29 & 29 & 29 & 29 \\
\hline $0.31-0.40$ & Mean & 99 & 43 & 57 & 752 & 13 \\
& Minimum & 66 & 28 & 35 & 346 & 7 \\
& Maximum & 158 & 61 & 102 & 1524 & 23 \\
& \% TDN & & 43 & 57 & & \\
& No. of samples & 23 & 23 & 23 & 23 & 23 \\
\hline \multirow{2}{*}{$>0.40$} & Mean & 77 & 41 & 36 & 693 & 24 \\
& Minimum & 36 & 22 & 5 & 394 & 11 \\
& Maximum & 110 & 55 & 64 & 982 & 62 \\
& \% TDN & & 53 & 47 & & 12 \\
& No. of samples & 12 & 12 & 12 & 12 & \\
\hline & & & & & \\
\hline
\end{tabular}


Table 3: Annual and seasonal flow-weighted dissolved N and DOC concentrations ( $\mu$ mol $l^{-1}$ ), and DOC:DON molar ratio under combined flow, stormflow and baseflow conditions

\begin{tabular}{|c|c|c|c|c|c|c|c|c|c|c|c|c|c|c|c|}
\hline & \multicolumn{5}{|c|}{ Combined Stormflow and Baseflow } & \multicolumn{5}{|c|}{ Stormflow } & \multicolumn{5}{|c|}{ Baseflow } \\
\hline & TDN & DIN & DON & DOC & $\begin{array}{l}\text { DOC: } \\
\text { DON }\end{array}$ & TDN & DIN & DON & DOC & $\begin{array}{l}\text { DOC: } \\
\text { DON }\end{array}$ & TDN & DIN & DON & DOC & $\begin{array}{l}\text { DOC: } \\
\text { DON }\end{array}$ \\
\hline \multicolumn{16}{|l|}{ Annual } \\
\hline Mean & 83.0 & 40.5 & 42.4 & 773 & 23.0 & 92.2 & 42.9 & 49.3 & 795 & 18.5 & 58.2 & 34.2 & 24.0 & 714 & 35.1 \\
\hline Median & 80.2 & 41.4 & 41.2 & 734 & 15.4 & 86.9 & 44.7 & 45.0 & 746 & 14.8 & 50.4 & 29.7 & 22.2 & 460 & 39.8 \\
\hline 10th Percentile & 45.8 & 20.6 & 12.8 & 296 & 8.00 & 49.9 & 24.9 & 19.7 & 354 & 8.18 & 41.3 & 17.9 & 7.76 & 174 & 6.26 \\
\hline 90th Percentile & 132 & 59.2 & 81.1 & 1366 & 46.1 & 139 & 60.2 & 89.8 & 1376 & 34.6 & 91.4 & 53.2 & 40.8 & 1312 & 56.5 \\
\hline Min & 29.2 & 6.95 & 2.56 & 132 & 3.43 & 35.9 & 13.3 & 3.05 & 183 & 7.36 & 29.2 & 6.95 & 2.56 & 132 & 3.43 \\
\hline $\operatorname{Max}$ & 163 & 73.0 & 102 & 1556 & 98.7 & 163 & 73.0 & 102 & 1524 & 77.4 & 117 & 71.3 & 57.5 & 1556 & 98.7 \\
\hline SE & 3.04 & 1.33 & 2.22 & 38.2 & 1.60 & 3.48 & 1.47 & 2.57 & 41.3 & 1.35 & 3.61 & 2.64 & 2.33 & 87.0 & 3.98 \\
\hline No. of samples & 121 & 121 & 121 & 121 & 121 & 88 & 88 & 88 & 88 & 88 & 33 & 33 & 33 & 33 & 33 \\
\hline \multicolumn{16}{|l|}{ Winter } \\
\hline Mean & 77.7 & 39.7 & 38.0 & 372 & 11.9 & 76.8 & 37.8 & 39.0 & 395 & 12.4 & 85.6 & 56.8 & 28.8 & 158 & 7.10 \\
\hline Median & 78.7 & 36.7 & 42.4 & 368 & 8.65 & 77.4 & 35.8 & 43.1 & 372 & 8.68 & 84.1 & 50.8 & 31.7 & 161 & 5.31 \\
\hline 10th Percentile & 68.7 & 29.3 & 13.5 & 183 & 7.38 & 67.8 & 29.0 & 17.1 & 342 & 7.60 & 80.8 & 48.8 & 16.6 & 148 & 3.81 \\
\hline 90th Percentile & 92.9 & 54.8 & 48.2 & 476 & 12.6 & 92.5 & 49.5 & 48.6 & 477 & 13.2 & 91.1 & 67.2 & 40.0 & 167 & 11.1 \\
\hline Min & 35.9 & 22.4 & 11.7 & 144 & 3.43 & 35.9 & 22.4 & 11.7 & 183 & 7.36 & 80.0 & 48.3 & 12.8 & 144 & 3.43 \\
\hline Max & 97.2 & 73.0 & 54.2 & 834 & 61.8 & 97.2 & 73.0 & 54.2 & 834 & 61.8 & 92.9 & 71.3 & 42.0 & 168 & 12.6 \\
\hline $\mathrm{SE}$ & 2.49 & 2.28 & 2.16 & 23.2 & 1.99 & 2.69 & 2.17 & 2.19 & 21.5 & 2.17 & 3.81 & 7.28 & 8.56 & 7.05 & 2.78 \\
\hline No. of samples & 31 & 31 & 31 & 31 & 31 & 28 & 28 & 28 & 28 & 28 & 3 & 3 & 3 & 3 & 3 \\
\hline \multicolumn{16}{|l|}{ Spring } \\
\hline Mean & 100 & 52.4 & 47.5 & 669 & 14.5 & 103 & 52.6 & 50.2 & 762 & 15.9 & 88.7 & 51.9 & 36.8 & 299 & 8.87 \\
\hline Median & 102 & 53.5 & 50.4 & 729 & 14.5 & 107 & 53.9 & 51.2 & 762 & 14.8 & 89.7 & 52.9 & 39.2 & 258 & 6.84 \\
\hline 10th Percentile & 76 & 41.6 & 27.2 & 306 & 7.18 & 82.2 & 41.1 & 37.7 & 595 & 13.3 & 66.4 & 46.4 & 17.6 & 163 & 5.47 \\
\hline 90th Percentile & 119 & 60.8 & 63.3 & 891 & 17.5 & 121 & 60.9 & 63.6 & 898 & 18.0 & 110 & 56.4 & 53.5 & 475 & 14.3 \\
\hline Min & 58.1 & 32.6 & 14.1 & 132 & 4.69 & 69.5 & 32.6 & 17.6 & 574 & 12.4 & 58.1 & 44.0 & 14.1 & 132 & 4.69 \\
\hline Max & 124 & 62.3 & 71.3 & 946 & 32.7 & 124 & 62.3 & 71.3 & 946 & 32.7 & 117 & 59.4 & 57.5 & 533 & 14.5 \\
\hline SE & 3.16 & 1.35 & 2.59 & 41.1 & 0.91 & 3.18 & 1.62 & 2.55 & 24.3 & 0.84 & 8.50 & 2.10 & 6.78 & 62.6 & 1.75 \\
\hline No. of samples & 30 & 30 & 30 & 30 & 30 & 24 & 24 & 24 & 24 & 24 & 6 & 6 & 6 & 6 & 6 \\
\hline \multicolumn{16}{|l|}{ Summer } \\
\hline Mean & 105 & 46.6 & 58.8 & 1062 & 27.8 & 118 & 48.2 & 69.5 & 1212 & 22.3 & 44.1 & 38.7 & 5.33 & 313 & 60.6 \\
\hline Median & 117 & 47.6 & 68.2 & 1233 & 16.7 & 132 & 50.5 & 81.1 & 1303 & 16.4 & 41.2 & 36.9 & 4.28 & 296 & 51.9 \\
\hline 10th Percentile & 41.1 & 32.8 & 4.99 & 315 & 14.3 & 50.2 & 36.1 & 18.7 & 922 & 14.1 & 40.3 & 31.9 & 2.82 & 243 & 43.0 \\
\hline 90th Percentile & 157 & 56.0 & 102 & 1477 & 55.3 & 157 & 58.4 & 102 & 1478 & 35.9 & 50.4 & 47.5 & 8.47 & 403 & 85.2 \\
\hline Minimum & 40.1 & 25.2 & 2.56 & 230 & 13.7 & 40.1 & 25.2 & 5.07 & 399 & 13.7 & 40.2 & 31.1 & 2.56 & 230 & 40.0 \\
\hline Maximum & 163 & 63.2 & 102 & 1524 & 98.7 & 163 & 63.2 & 102 & 1524 & 77.4 & 55.5 & 52.3 & 9.19 & 460 & 98.7 \\
\hline SE & 8.28 & 1.79 & 6.90 & 78.9 & 4.08 & 7.84 & 1.88 & 6.35 & 58.0 & 3.16 & 2.89 & 3.74 & 1.27 & 39.5 & 13.0 \\
\hline No. of samples & 30 & 30 & 30 & 30 & 30 & 25 & 25 & 25 & 25 & 25 & 5 & 5 & 5 & 5 & 5 \\
\hline \multicolumn{16}{|l|}{ Autumn } \\
\hline Mean & 49.0 & 23.5 & 25.5 & 1002 & 39.0 & 50.7 & 22.9 & 27.8 & 938 & 32.3 & 48.0 & 23.8 & 24.2 & 1039 & 42.5 \\
\hline Median & 49.5 & 22.6 & 26.4 & 1158 & 39.6 & 50.7 & 16.8 & 28.9 & 1008 & 33.7 & 48.2 & 23.5 & 22.7 & 1195 & 42.0 \\
\hline 10th Percentile & 44.0 & 14.2 & 16.4 & 336 & 22.7 & 44.3 & 14.2 & 20.1 & 491 & 24.1 & 43.6 & 17.3 & 15.8 & 315 & 21.6 \\
\hline 90th Percentile & 53.7 & 35.2 & 36.0 & 1333 & 52.4 & 56.3 & 37.4 & 36.5 & 1331 & 37.7 & 53.1 & 30.7 & 33.1 & 1342 & 58.2 \\
\hline Minimum & 29.2 & 6.95 & 3.05 & 249 & 15.6 & 43.4 & 13.3 & 3.05 & 399 & 22.7 & 29.2 & 6.95 & 9.61 & 249 & 15.6 \\
\hline Maximum & 59.0 & 50.2 & 39.1 & 1556 & 69.9 & 59.0 & 50.2 & 39.1 & 1348 & 43.5 & 54.5 & 44.0 & 37.7 & 1556 & 69.9 \\
\hline SE & 0.99 & 1.70 & 1.60 & 71.3 & 2.35 & 1.44 & 3.62 & 3.09 & 108 & 2.05 & 1.30 & 1.75 & 1.78 & 94.8 & 3.16 \\
\hline No. of samples & 30 & 30 & 30 & 30 & 30 & 11 & 11 & 11 & 11 & 11 & 19 & 19 & 19 & 19 & 19 \\
\hline
\end{tabular}


Table 4: Bivariate Pearson correlation between nutrient concentrations $\left(\mu \mathrm{mol} 1^{-1}\right.$ ) and ratios. Correlations are shown at $p<0.01$

\begin{tabular}{|c|c|c|c|}
\hline & & Baseflow & Stormflow \\
\hline \multirow[t]{4}{*}{ Annual } & DON vs DOC & - & 0.69 \\
\hline & DON vs DIN & - & 0.44 \\
\hline & DIN vs DOC & -0.81 & - \\
\hline & DIN vs DOC:DON & -0.52 & -0.38 \\
\hline \multirow[t]{4}{*}{ Winter } & DON vs DOC & - & - \\
\hline & DON vs DIN & - & - \\
\hline & DIN vs DOC & - & - \\
\hline & DIN vs DOC:DON & - & - \\
\hline \multirow[t]{4}{*}{ Spring } & DON vs DOC & - & 0.83 \\
\hline & DON vs DIN & - & - \\
\hline & DIN vs DOC & - & - \\
\hline & DIN vs DOC:DON & - & - \\
\hline \multirow[t]{4}{*}{ Summer } & DON vs DOC & - & 0.95 \\
\hline & DON vs DIN & - & 0.74 \\
\hline & DIN vs DOC & - & 0.60 \\
\hline & DIN vs DOC:DON & - & -0.62 \\
\hline \multirow[t]{4}{*}{ Autumn } & DON vs DOC & 0.78 & 0.85 \\
\hline & DON vs DIN & -0.73 & -0.92 \\
\hline & DIN vs DOC & -0.73 & -0.90 \\
\hline & DIN vs DOC:DON & - & -0.78 \\
\hline
\end{tabular}


Table 5: Bivariate Pearson correlations between temperature $\left({ }^{\circ} \mathrm{C}\right)$, and the concentration of $\mathrm{N}$ species and DOC $\left(\mu \mathrm{mol} \mathrm{1}{ }^{-1}\right)$. Correlations are shown at $p<0.01(* *)$ and $p<0.05(*)$.

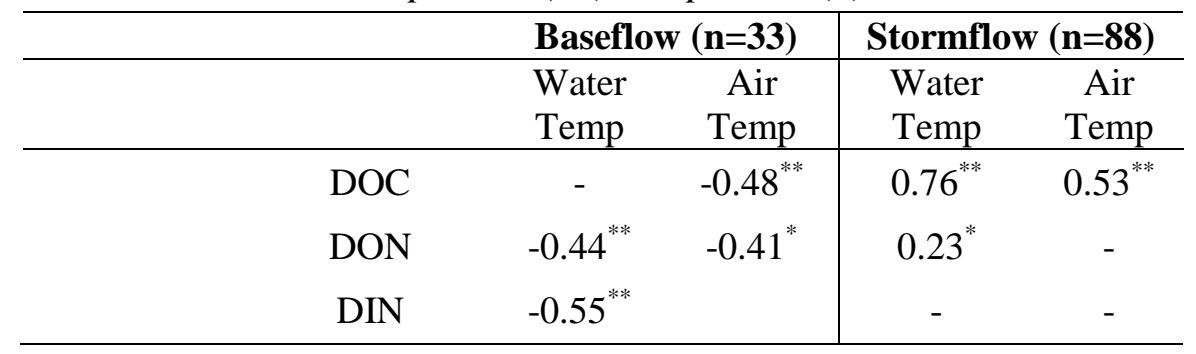


Table 6: Annual and seasonal $\mathrm{N}$ fluxes shown in $\mathrm{kg} \mathrm{N}^{-1} \mathrm{yr}^{-1}$ using the rating curve technique including error of the estimate; Walling and Webb (1985) 'method 5' shown in parentheses and simple hydrograph separation technique shown in square brackets

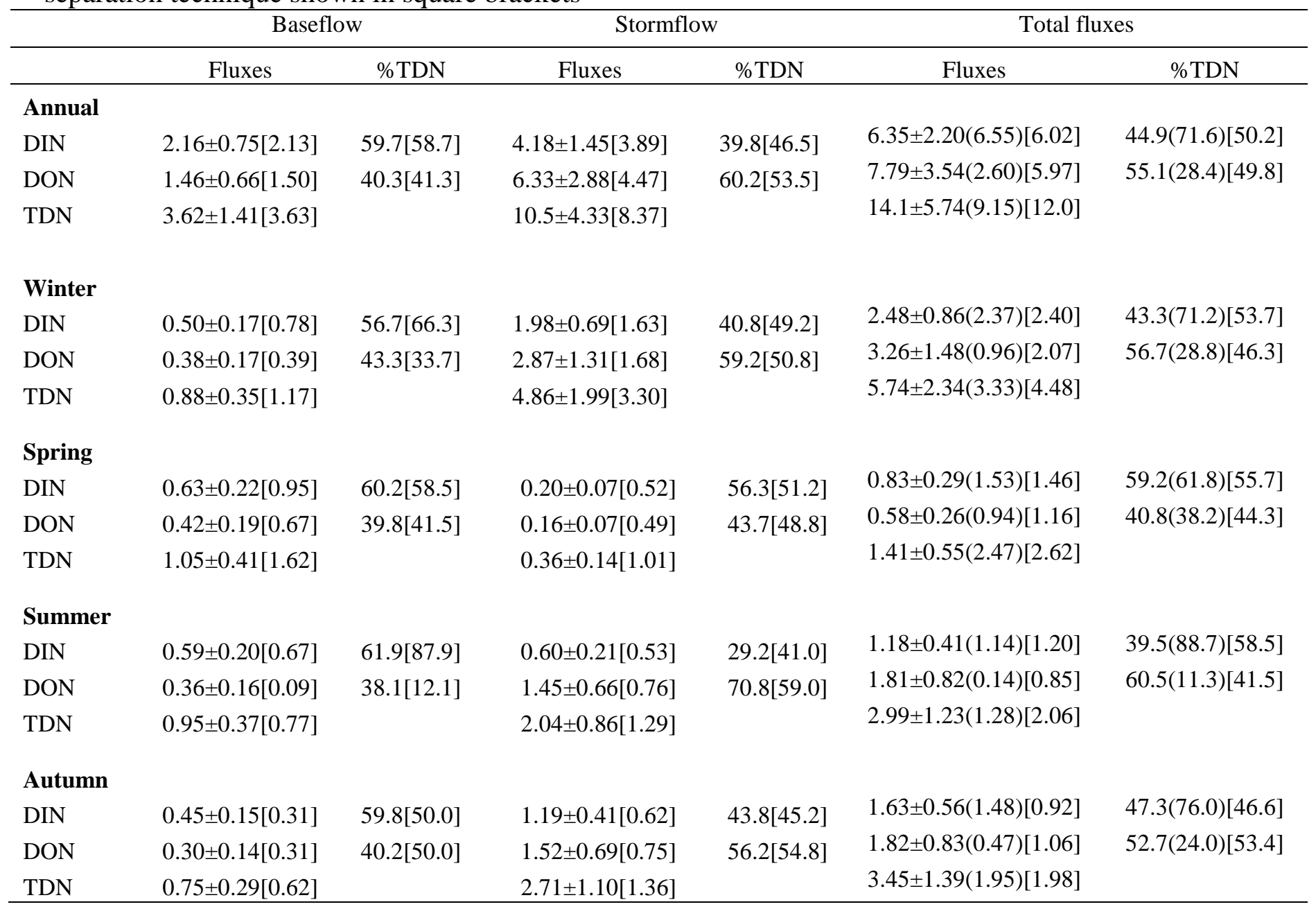


Table 7: Best estimate of annual and seasonal $\mathrm{N}$ fluxes $\left(\mathrm{kg} \mathrm{N} \mathrm{ha}^{-1} \mathrm{yr}^{-1}\right)$ for the Kinder River

\begin{tabular}{cccc}
\hline & & Fluxes & \% TDN \\
\hline Annual & DIN & 6.55 & 45.7 \\
& DON & 7.79 & 54.3 \\
& TDN & 14.3 & \\
Winter & DIN & 2.37 & 42.1 \\
& DON & 3.26 & 57.9 \\
& TDN & 5.63 & \\
& & & \\
Spring & DIN & 1.53 & 72.5 \\
& DON & 0.58 & 27.5 \\
& TDN & 2.11 & \\
& & & \\
Summer & DIN & 1.14 & 38.6 \\
& DON & 1.81 & 61.4 \\
& TDN & 2.95 & \\
& & & \\
Autumn & DIN & 1.48 & 44.8 \\
& DON & 1.82 & 55.2 \\
& TDN & 3.30 & \\
\hline
\end{tabular}


Table 8: N input-output budget for the Kinder River catchment (Dec 2012-Nov 2013). NB: Atmospheric inorganic $\mathrm{N}$ input for the catchment is represented by the average inorganic $\mathrm{N}$ deposition value for the south Pennines (Helliwell et al., 2007b)

\begin{tabular}{lcccc}
\hline \multicolumn{1}{c}{ N Budget } & $\mathrm{kg} \mathrm{N} \mathrm{ha}^{-1} \mathrm{yr}^{-1}$ & \%retained & \%export & Status \\
\hline Atmospheric inorganic N input & 28.0 & & & \\
Fertilizer input & 19.5 & & & \\
Total input & 47.5 & & & \\
\hline Fluvial output of DIN & 6.55 & & & \\
Input - Output & 41.0 & $86 \%$ & $14 \%$ & Sink \\
\hline Fluvial output of TDN (DIN+DON) & 14.3 & & & \\
Input - Output & 33.2 & $70 \%$ & $30 \%$ & Sink \\
\hline
\end{tabular}




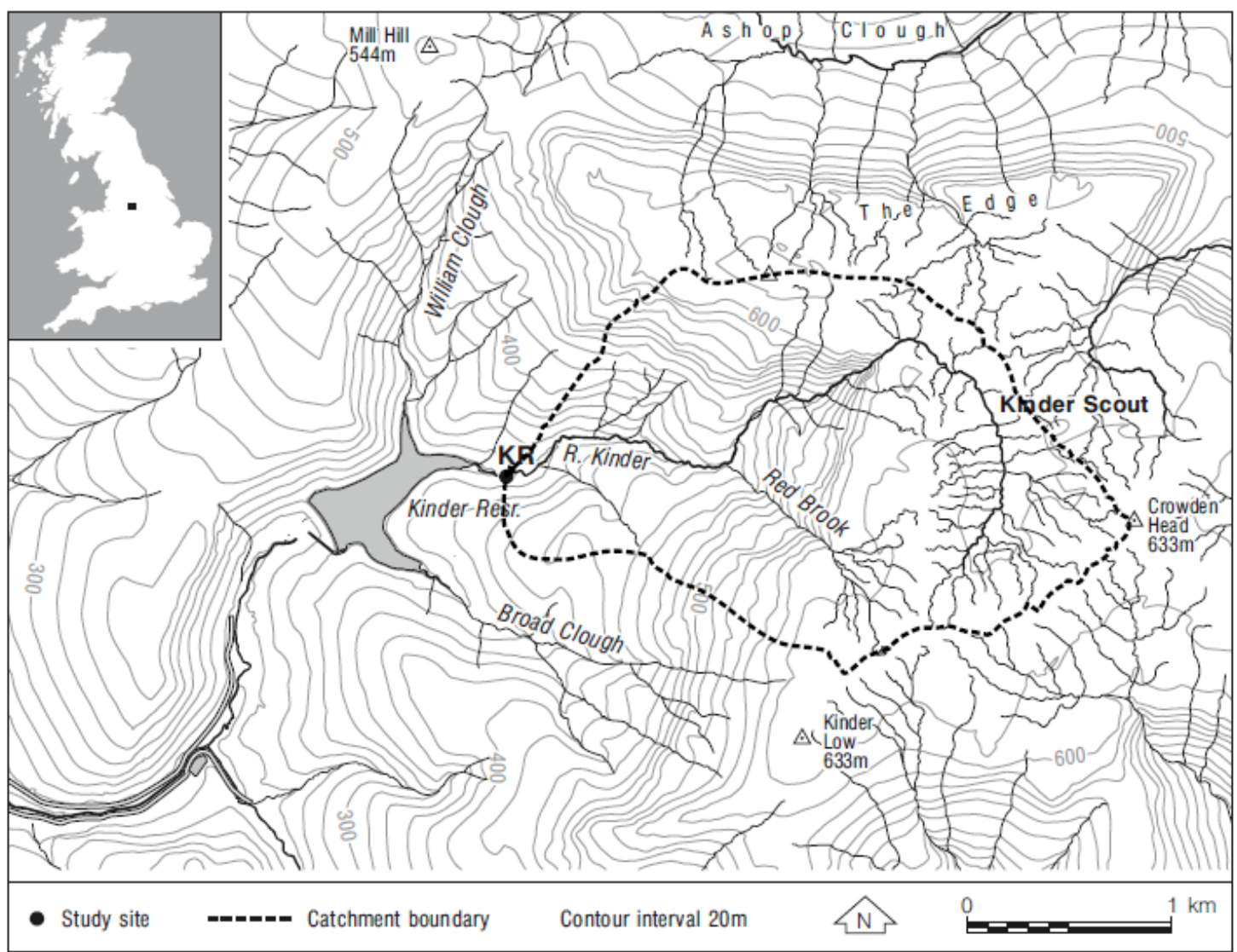

Figure 1: Study site location 

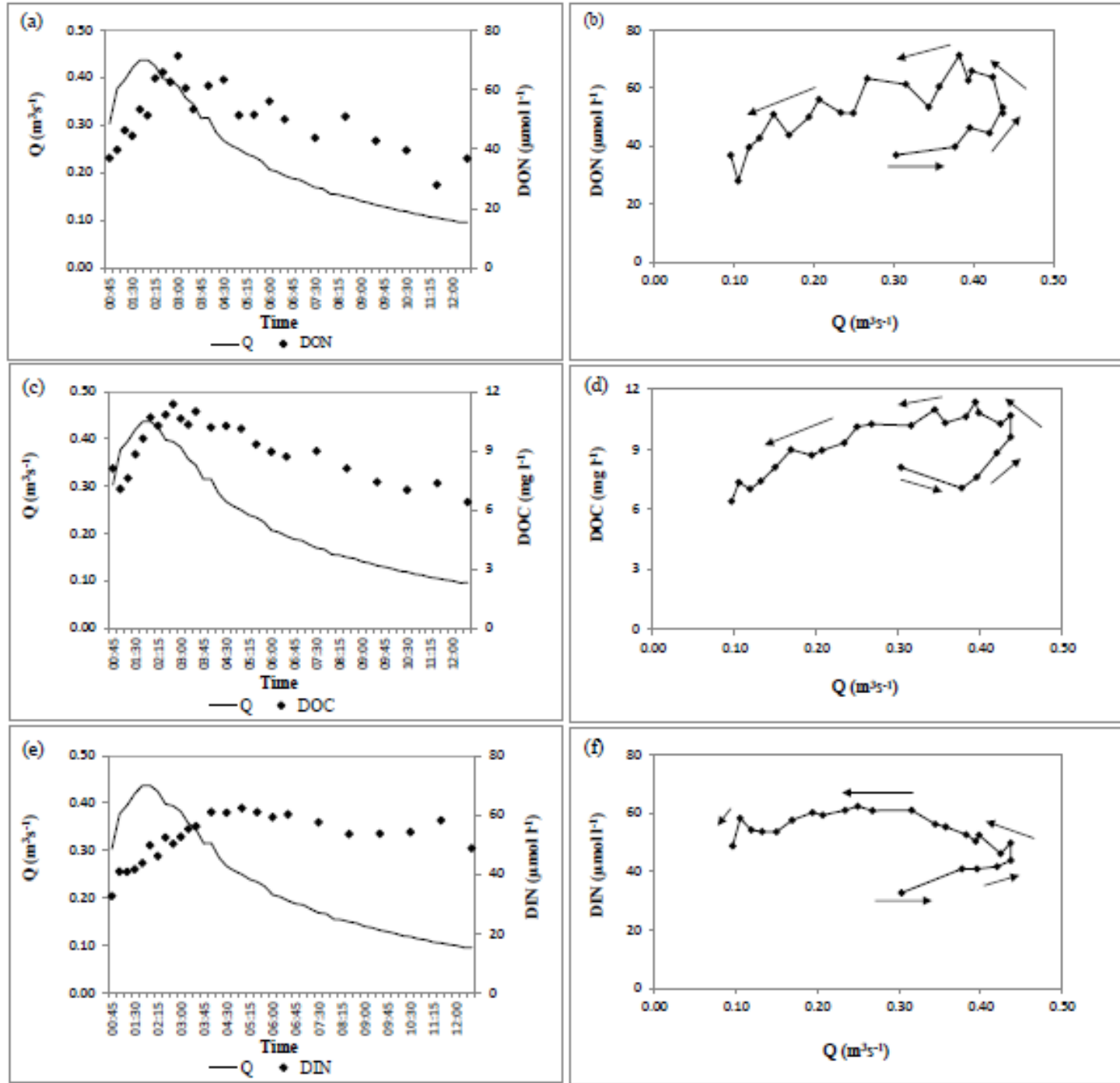

Figure 2: Concentration-discharge (C-Q) relationships and hysteresis loops for DON (a, b), DOC (c, d) and DNN (e, f) during a spring storm event (12/05/2013). 

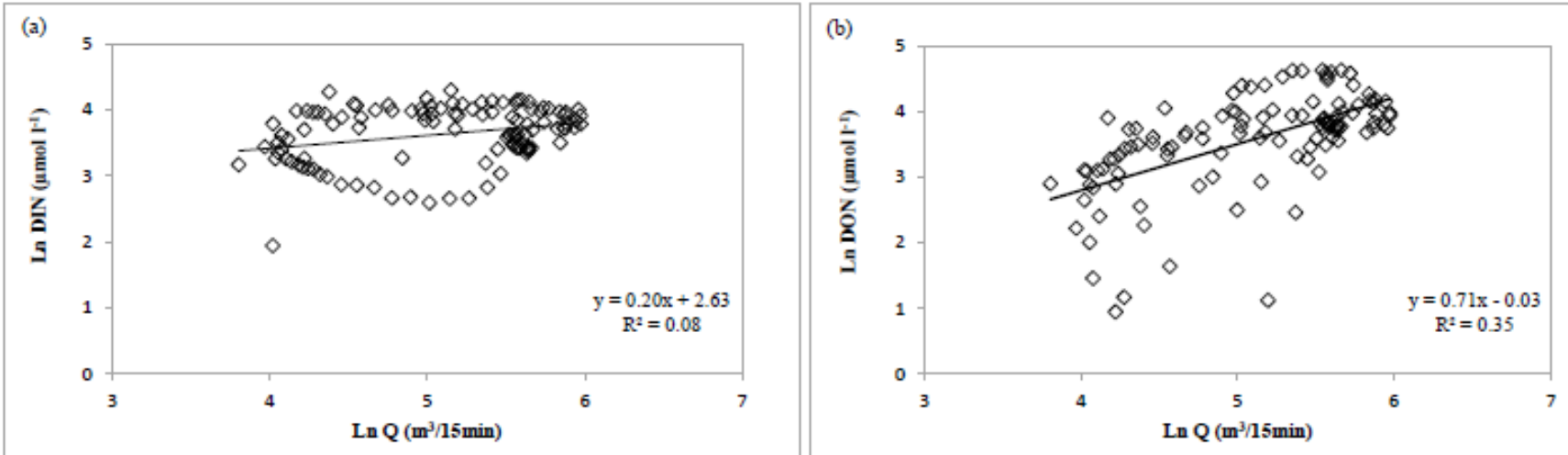

Figure 3: Linear regression relationship between discharge (Q) and DIN (a) and DON (b) for Kinder River water samples. 